\title{
International Family Migration and the Dual-Earner Model
}

\author{
Martin D. Munk* \\ Till Nikolka ${ }^{\dagger}$ \\ Centre for Mobility Research, \\ Ifo Institute, Germany \\ Aalborg University, Denmark \\ Panu Poutvaara ${ }^{\ddagger}$ \\ University of Munich, Ifo Institute, CESifo and IZA, Germany \\ CReAM, United Kingdom
}

\begin{abstract}
Gender differences in labor force participation are exceptionally small in Nordic countries.

We investigate how couples emigrating from Denmark self-select and sort into different destinations and whether couples pursue the dual-earner model, in which both partners work, when abroad. Female labor force participation is slightly lower among couples that later emigrate, and drops considerably after migration outside the Nordic countries. Pre-migration differences between couples subsequently migrating to different destinations are small. Our survey reveals that couple migration is usually driven by the male's job opportunities. The results suggest that increasing international migration may reduce women's career investments.
\end{abstract}

JEL-Classification: D13, J12, J13, J16, F22

Keywords: Household production, Female labor force participation, Child care, International migration, Family migration

We thank Christina Fong, Paola Profeta, Helmut Rainer, Maximilian Schwefer, Madhinee Valeyatheepillay, as well as participants at the 4th Norface Migration Conference, 12th Journees LAGV, 71st IIPF Annual Congress as well as seminar participants at Brunel University and the University of Exeter for useful comments. Financial support from the Leibniz Association (SAW-2012-ifo-3) and from the Danish Council for Independent Research | Social Sciences (FSE) is gratefully acknowledged.

\footnotetext{
*Aalborg University, Dept. of Pol. Sci., A C Meyers Vaenge 15, FKJ10B-3, DK-2450 Copenhagen SV, Denmark. Email: mdm@dps.aau.dk

${ }^{\dagger}$ Ifo Institute, Poschingerstr. 5, 81679 Munich, Germany. Email: nikolka@ifo.de, Phone: +49(0)89/9224-1392

${ }^{\ddagger}$ Ifo Institute, Poschingerstr. 5, 81679 Munich, Germany. Email: poutvaara@ifo.de, Phone: +49(0)89/9224-1372, Fax: $+49(0) 89 / 9224-1462$
} 


\section{Introduction}

A couple considering migration might face a trade-off in whose career to prioritize. An important question from a societal perspective is hence whether post-migration changes in labor force participation and intra-household resource allocation reflect both partners' preferences, or whether migration hurts one of the partners. Previous research on internal migration has found that couple migration is typically associated with career gains for men, with women often leaving the labor market or at least reducing the hours worked (Mincer, 1978; Frank, 1978). As partners may differ in the international transferability of their education and in their language skills, international migration is likely to impose even more difficult trade-offs. This is of increasing importance in globalized economies, affecting investments in education and the international allocation of talent as well as firm competitiveness. Furthermore, if women would expect a high probability that they would later emigrate due to their partner's job opportunities, this would reduce their incentives to invest in their own career. In the light of assortative mating, this could be expected to affect disproportionately women who might otherwise pursue an ambitious career. Given that early investments in career are made before the realizations of own and partner's job opportunities abroad are revealed, this would affect the incentives beyond the group that actually emigrates. However, so far there is no research linking pre-migration and post-migration outcomes in the context of international family migration.

In this paper, we first present a theoretical model in which partners jointly choose the optimal allocation of available time for labor supply and household production. Depending on wage rates, gender identity and, in the presence of children, the price of child care, couples may prefer either a dual-earner model in which both partners work outside the home, or a male breadwinner model in which only the male works outside the home. We then use the predictions of the model to guide our empirical analysis on labor force participation among migrant couples from Denmark in different destinations. Second, to test the role of Tiebout sorting, we use administrative data on the whole population to analyze how couples migrating to different destinations self-select according to the partners' labor force participation in Denmark. Third, with a representative survey of Danish emigrants we study why couples emigrate, to what extent emigration is a shared preference of the partners, and how labor force participation abroad differs from the pre-migration situation. We restrict attention to couples in which both partners are Danes as migration decisions of couples in which one partner returns to his or her home country might be qualitatively different. The survey data is combined with the full Danish population administrative data to evaluate to what extent 
our survey respondents are representative of the underlying population.

Our model allows both a gender neutral set-up and the possibility of gendered specialization in the household. Gender identity norms could result in a preference for the male breadwinner model. For example, Bertrand et al. (2015) conclude that a large fraction of American couples is averse to a situation in which the female earns more than the male. In international comparison, Denmark has higher female labor force participation rates than most other countries (75.0\%, OECD, 2015) and ranks third among all countries in gender equality according to Klugman (2011). Goldin (2006) called women's increased labor force participation "the most significant change in labor markets during the past century". The Nordic countries have pioneered this change promoted by generously subsidized child care services, and also by heavy income taxation at the individual level. Irrespective of whether specialization in household production follows from comparative advantage or gender identity, our model predicts that the likelihood that the secondary earner works is increasing in the secondary earner's relative wage. A revealed preference argumentation suggests that a partner whose job was the main reason for the couple to emigrate must gain, which in turn implies that the labor force participation of the tied mover (who can generally be expected to be the secondary earner) is likely to decrease. Our model suggests that labor force participation rates of women who are tied movers are linked to income differences in various destination countries. Moreover, based on the model's comparative statics we expect female labor force participation to be lower among couples with children, especially among those with young children in countries without universal public child care. Both small income differences and generous child care services in other Nordic countries suggest that female labor force participation should be highest in these countries, being in line with the rates in Denmark. On the other hand, we would expect female labor force participation rates among Danish migrant couples to be lower in the United States (US) than in other Western countries, due to wider income differences in the US. The same would apply to non-Western destination countries.

Analyzing labor force participation and emigration decisions in the whole population of Danish couples we find that couples are more likely to emigrate if either partner is out of the labor force. Among couples migrating to the US, female labor force participation is somewhat lower before emigration compared to female labor force participation rates of couples migrating to other destinations. However, the vast majority of emigrant couples pursues a dual-earner model in Denmark before migration. We do not find different sorting of emigrants to other Western or non-Western countries in terms of pre-migration female labor force participation. Furthermore, regression anal- 
ysis shows that the effects of partners' education and children on female labor force participation in Denmark are quite similar among couples that do not migrate, among couples that migrate for one or more years, among couples that migrate for five or more years and among couples that have not returned to Denmark. ${ }^{1}$ Our survey data analysis sheds light on whether couples emigrating from egalitarian Nordic countries pursue the dual-earner model outside the Nordic countries, or if international mobility is associated with adopting a traditional male breadwinner model. Our main finding is that female labor force participation outside the Nordic countries is considerably lower than in Denmark while there are no changes in male labor force participation patterns.

Our finding of lower female labor force participation outside the Nordic countries could reflect both demand and supply side effects. As for demand side effects, women who migrate with their partner might not be able to find a job matching their qualifications, thus suffering a loss as tied movers. However, survey data reveals that reduced labor force participation among most couples is in line with the partners' preferences. On the labor supply side, there are four potential explanations for lower female labor force participation rates outside the Nordic countries. First, our model suggests that wider wage differences between the partners abroad compared with Denmark can be a reason for reduced female labor force participation. Second, couples with children might face a higher price for child care services in other countries as compared to the price in Denmark which makes it less attractive for both partners to participate in the labor force. Third, lower female labor force participation among the migrant couples could be due to assimilation towards prevailing social norms in the destination country. Fourth, reduced female labor force participation might be driven by self-selection to different destinations according to the partners' preferences towards the division of labor.

Empirical analysis confirms that female labor force participation is lower among couples living in countries where incomes are more dispersed, as measured by the GINI coefficient, as well as in countries with less affordable child care. Prevailing female labor force participation rates in the countries of residence, instead, fail to explain the observed differences in female labor force participation among the migrant couples. As for self-selection into migration, we find slightly lower female labor force participation in Denmark among couples migrating to the US compared to those migrating to other Western countries. There are no differences in female labor force participation

\footnotetext{
${ }^{1}$ When using register data, we analyze different duration criteria separately as Borjas and Bratsberg (1996) found that accounting for return migration accentuates the self-selection of immigrants to the US. Dustmann and Görlach (2016) show that a large share of international migration is temporary. Our survey data is restricted to Danish emigrants who have not returned.
} 
in Denmark between couples subsequently migrating to the Nordic countries, the other Western countries, and the non-Western countries. While migrants do not differ much from non-migrants in terms of pre-migration female labor force participation, this does not rule out strong self-selection in terms of preferences. We find that most male survey respondents migrated for own work reasons and most females for family reasons, with migration almost always being a shared preference although driven by male preferences in a sizable minority of couples. Furthermore, couples migrating to different destinations differ considerably with respect to their main motivations to emigrate and preferred female labor force participation.

We make three main contributions to the previous literature on family migration. First, we obtain direct evidence on partners' stated motivations to migrate and on whether migration was a joint preference, or if one partner was a tied mover who would have preferred not to migrate. Second, we analyze data on labor force participation before and after migration and address self-selection and sorting of the migrant couples with regard to labor force participation. Third, we analyze international migration. Due to data restrictions, most literature on family migration has focused on internal migration. The few papers that have analyzed international migration in the family context have looked at labor force participation or earnings only in the destination country (Borjas and Bronars, 1991; Cobb-Clark, 1993), or only in the country of origin (Junge et al., 2014; Foged, 2016). ${ }^{2}$ Junge et al. (2014) show that the likelihood that a dual-earner couple emigrates increases strongly in the earnings of the primary earner. Foged (2016) shows that a similar result holds also when using partners' predicted earnings potentials, based on nine education categories.

Earlier migration research has focused extensively on migration from poor to rich countries, but migration flows between rich countries are also substantial. In 2013, 22 million persons born in one of the EU15 countries ${ }^{3}$ lived outside their country of origin. Out of those, $42 \%$ lived in another EU15 country and an additional 13\% in the US (United Nations, 2015). The pattern of emigration from Denmark is rather similar. In 2013, over a quarter million Danes lived outside Denmark (corresponding to about $5 \%$ of the Danish-born population), with $50 \%$ of the migrants living in other EU15 countries and 13\% in the US (United Nations, 2015). Emigration rates from Denmark are neither exceptionally low nor exceptionally high when comparing across European countries. In 2012 , the emigration rate among the 25 to 54 year old native-born population was $0.33 \%$ in

\footnotetext{
${ }^{2}$ There is an extensive literature on the effects of temporary migration of family members on those left behind in the home country, for example through remittances. For a survey see Docquier and Rapoport (2006).

${ }^{3}$ This country group includes: Austria, Belgium, Denmark, Finland, France, Germany, Greece, Ireland, Italy, Luxembourg, the Netherlands, Portugal, Spain, Sweden, and the United Kingdom.
} 
Denmark, $0.18 \%$ in Germany, $1.19 \%$ in Ireland, $0.37 \%$ in the Netherlands, $0.13 \%$ in Spain, and $0.29 \%$ in Sweden (Eurostat 2016).

Our findings raise intriguing questions about family preferences towards the dual-earner and the male breadwinner model, also outside the context of migration. One third of couples that have emigrated outside the Nordic countries prefer that only the male works, in a stark contrast to the Nordic countries in which only one in sixteen couples prefers that the male works and the female stays at home. We find small pre-migration differences in female labor force participation between couples that subsequently migrated to different destinations. Pre-migration female labor force participation among couples that subsequently emigrate is lower compared with non-migrant couples but only a small fraction of female partners is out of the labor force before emigration. Furthermore, especially women migrating to the US and non-Western countries viewed escaping stressful working life as an argument in favor of emigration, and very few against. This suggests that a large fraction of couples emigrating to these countries preferred to switch from a dual-earner model to a male breadwinner model. Those preferring a dual-earner model might choose to stay in Denmark or to go to another Nordic country in which generous welfare services, especially child care provision, make combining work and family easier, in order to avoid the female being pushed out of the labor force. As it is unlikely that all couples preferring a male breadwinner model would go as far as to emigrate, an open question is how many of the dual-earner couples living in egalitarian Nordic countries would actually prefer the traditional male breadwinner model, if wider income differences would allow a high living standard with only one partner working. The big differences in labor force participation between emigrant couples in different destinations are likely to reflect a joint effect of self-selection in terms of preferences and labor supply adjustments as a reaction to different relative wage rates and price and availability of child care services.

The rest of the paper is organized as follows. Section 2 presents the theoretical model from which we derive hypotheses to be tested in our empirical analysis. We describe our data in section 3 and summarize stylized facts in section 4. Section 5 presents our econometric analysis. Section 6 concludes.

\section{Theoretical Framework}

We consider a household consisting of two adult partners, $a$ and $b$ (and possibly children who do not make any decisions). Partners derive utility from consumption $C$ and household production 
$H$ and divide their working time between labor market activity and the production of a household public good. The time available for work and household production is equal to one for each partner. The partners make their decision on how much time to spend on household production $H_{a}, H_{b}$ and how much time to spend on working in the labor market $\left(1-H_{a}\right),\left(1-H_{b}\right)$ in a simple unitary household economy as proposed by Becker $(1974,1991)$, i.e. they maximize joint household utility. ${ }^{4}$ Household production is linear so that $H=H_{a}+H_{b}$. According to the standard framework, the specialization in either household or labor market work would arise due to either partner's comparative advantage. However, gender identity might also have a large impact on the division of labor in the household (John and Shelton, 1996, Bertrand et al. 2015; for a survey see Bertrand, 2011).

We write the couple's utility in the Cobb-Douglas form with $0<\alpha<1$ being the weight of market good consumption and $1-\alpha$ being the weight of household production. Couples with children additionally enjoy utility $\psi$, but have to provide child care $\bar{D}<1$ for the children. Couples can choose how much of the required child care to buy on the market $(D, D \leq \bar{D})$ and how much to provide privately $(\bar{D}-D)$. The time spent on child care is not available for other household production. For couples without children $\psi=0, \bar{D}=0$ and thus $D=0$. The presence of children is given exogenously as we do not focus on fertility decisions in this analysis. Wage rates are $w_{a}$ for partner $a$ and $w_{b}$ for partner $b$. Child care can be bought for the price $p_{D}$ per time unit. We write household utility as

$$
U=C^{\alpha}\left(H_{a}+H_{b}-\bar{D}+D\right)^{1-\alpha}+\psi-\lambda I\left(H_{a}>0 \wedge H_{b}<1\right)
$$

with

$$
C=\left(1-H_{a}\right) w_{a}+\left(1-H_{b}\right) w_{b}-p_{D} D
$$

If the household does not have a preference for partner $a$ specializing in the labor market and $b$ specializing in household production, independently of who earns more, $\lambda=0$. In this case the partner with the higher wage specializes in labor market work and the partner with the lower wage in household production. The model allows the case in which partners may have a preference towards certain family model independent of the partners' earnings potentials. Such a preference could reflect gender identity norms as Akerlof and Kranton (2000) suggest. If $\lambda>>0$, then partner

\footnotetext{
${ }^{4}$ Alternatively, collective models recognize that household members have their own preferences, and engage in bargaining. This approach was pioneered by Chiappori (1988, 1992) and Apps and Rees (1988). Our analytical results could be derived also from a collective model, at the cost of more complex notation. The relationship between our model and the richer collective model is discussed at the end of this section. See Browning et al. (2014) for an overview on the unitary, cooperative and non-cooperative models of the family.
} 
$a$ will always specialize in the labor market and $b$ in household production. If partner $a$ is male and partner $b$ is female, this can be interpreted as a preference for a traditional male breadwinner model, giving priority to male labor market opportunities even if $w_{a}<w_{b}$ as long as $\lambda$ is sufficiently large. The optimal time allocation $H_{a}^{*}$ and $H_{b}^{*}$ is given by

Proposition 1. (i) If $w_{a} \geq w_{b}$ and $w_{b}<p_{D}$,

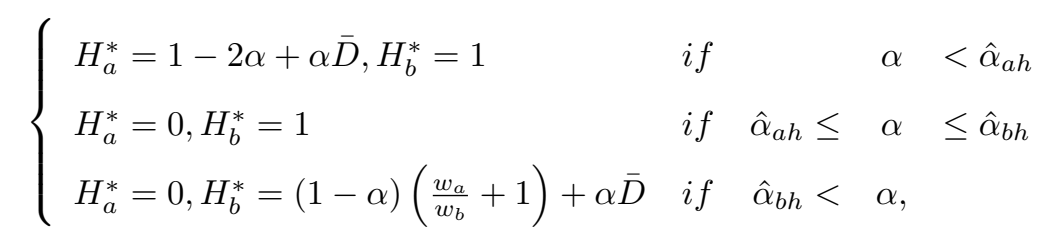

$\hat{\alpha}_{a h}=\frac{1}{2-\bar{D}} \quad$ being the threshold below which $a$ starts working in the household and $\hat{\alpha}_{b h}=\frac{w_{a}}{w_{a}+w_{b}-w_{b} \bar{D}} \quad$ being the threshold above which $b$ participates in the labor force in case childcare is provided privately;

(ii) if $w_{a} \geq w_{b} \geq p_{D}$,

$$
\left\{\begin{array}{llr}
H_{a}^{*}=1-2 \alpha-(1-\alpha) \frac{p_{D}}{w_{a}} \bar{D}, H_{b}^{*}=1 & \text { if } \quad \alpha<\hat{\alpha}_{a m} \\
H_{a}^{*}=0, H_{b}^{*}=1 & \text { if } \quad \hat{\alpha}_{a m} \leq \alpha \leq \hat{\alpha}_{b m} \\
H_{a}^{*}=0, H_{b}^{*}=(1-\alpha)\left(\frac{w_{a}}{w_{b}}+1-\frac{p_{D}}{w_{b}} \bar{D}\right) & \text { if } \quad \hat{\alpha}_{b m}<\alpha
\end{array}\right.
$$

$\hat{\alpha}_{a m}=\frac{w_{a}-p_{D} \bar{D}}{2 w_{a}-p_{D} \bar{D}} \quad$ being the threshold below which $a$ starts working in the household and $\hat{\alpha}_{b m}=\frac{w_{a}-p_{D} \bar{D}}{w_{a}+w_{b}-p_{D} \bar{D}} \quad$ being the threshold above which $b$ participates in the labor force in case childcare is bought on the market;

(iii) if $w_{b}>w_{a}$ and $\lambda=0$, labor supply decisions are as in (i) and (ii), switching indices $a$ and $b$; (iv) if $w_{b}>w_{a}, \lambda>>0$, and $w_{b}<p_{D}$,

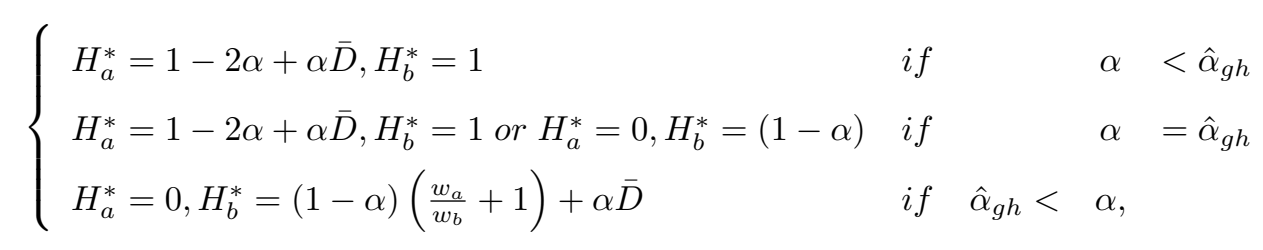

$\hat{\alpha}_{g h}=\frac{\ln \left(\frac{w_{a}+w_{b}-w_{b} \bar{D}}{\left(2-D w_{b}\right.}\right)}{\ln \left(\frac{w_{a}}{w_{b}}\right)}$ being the threshold below which $a$ starts working in the household and above which $b$ participates in the labor force in case childcare is provided privately; if $\alpha=\hat{\alpha}_{g m}$ both solutions yield the same utility;

(v) if $w_{b}>w_{a}, \lambda>>0$, and $w_{b} \geq p_{D}$, 


$$
\left\{\begin{array}{lll}
H_{a}^{*}=1-2 \alpha-(1-\alpha) \frac{p_{D}}{w_{a}} \bar{D}, H_{b}^{*}=1 & \text { if } & \alpha<\hat{\alpha}_{g m} \\
H_{a}^{*}=1-2 \alpha+\alpha \bar{D}, H_{b}^{*}=1 \text { or } H_{a}^{*}=0, H_{b}^{*}=(1-\alpha) & \text { if } \quad & \alpha=\hat{\alpha}_{g m} \\
H_{a}^{*}=0, H_{b}^{*}=(1-\alpha)\left(\frac{w_{a}}{w_{b}}+1-\frac{p_{D}}{w_{b}} \bar{D}\right) & \text { if } \quad \hat{\alpha}_{g m}<\quad \alpha
\end{array}\right.
$$

$\hat{\alpha}_{g m}=\frac{\ln \left(\frac{w_{a}^{2}+w_{a} w_{b}-w_{a} p_{D} \bar{D}}{2 w_{a} w_{b}-w_{b} p_{D} \bar{D}}\right)}{\ln \left(\frac{w_{a}}{w_{b}}\right)}$ being the threshold below which $a$ starts working in the household and above which $b$ participates in the labor force in case childcare is bought on the market; if $\alpha=\hat{\alpha}_{g m}$ both solutions yield the same utility.

Proof. See Appendix.

Proposition 1 defines optimal time allocation as a function of the weight that market consumption has in the household utility function. Below the lowest threshold in each regime depending on the relative size of $w_{a}, w_{b}$, and $p_{D}$, and associated with $\lambda=0$ or $\lambda>>0$, one of the partners fully specializes in household production and the other divides the time between household production and working in the labor market. Above the highest threshold, one of the partners fully specializes working in the labor market and the other divides the time between household production and working in the labor market. In cases (i), (ii) and (iii), corresponding to the situation in which the higher-earning partner is the first one to specialize in working in the labor market, there is also an intermediate parameter range in which the higher-earning partner works full time in the labor market and the lower-earning partner works full time in household production. In regimes (iv) and (v), corresponding to the case in which gender identity norms result in the lower-earning partner to specialize in working outside the household, such an intermediate range of both partners specializing fully does not exist. The reason for this is that the higher-earning partner always stays out of the labor market unless the lower-earning partner works full-time. With increasing marginal utility from consumption the lower-earning partner increases labor supply while the higher-earning partner remains out of the labor market up to a value of $\alpha=\hat{\alpha}_{g h}$ in case (iv) and $\alpha=\hat{\alpha}_{g m}$ in case (v). Above this value, the utility is higher when the higher-earning partner enters the labor market with a labor supply strictly above zero conditional on the lower-earning partner working full-time. As the higher-wage partner increases labor supply with increasing $\alpha$ at lower marginal cost of substitution it is not optimal for the couple to fully specialize before the higher-wage partner enters the labor market.

Comparative statics yield: 
Proposition 2. Extensive and intensive margin labor supply of the partner specializing in home production is weakly increasing with the own wage and weakly decreasing with the partner's wage.

Proof. Under (i), (ii), (iv) and (v)

$$
\frac{\partial \hat{\alpha}_{z}}{\partial w_{a}} \geq 0, \quad \frac{\partial \hat{\alpha}_{z}}{\partial w_{b}} \leq 0, \quad \frac{\partial H_{b}^{*}}{\partial w_{a}} \geq 0, \quad \frac{\partial H_{b}^{*}}{\partial w_{b}} \leq 0, \text { with } z \in\{b h, b m, g h, g m\} .
$$

For case (iii) the above expressions hold after switching indices $a$ and $b$.

Proposition 3. The labor supply of the partner specializing in home production is increasing (decreasing) with the time required for child care, provided that the wage rate of that partner is higher (lower) than the price of child care. If the wage rate of the partner specializing in home production is higher than the price of child care, this partner's labor supply is increasing with the price of child care.

Proof. Under (i) and (iv)

$$
\frac{\partial \hat{\alpha}_{z}}{\partial \bar{D}} \geq 0, \frac{\partial H_{b}}{\partial \bar{D}} \geq 0 \frac{\partial \hat{\alpha}_{z}}{\partial p_{D}}=0, \quad \frac{\partial H_{b}^{*}}{\partial p_{D}}=0, \text { with } z \in\{b h, g h\}
$$

and under (ii) and (v)

$$
\frac{\partial \hat{\alpha}_{z}}{\partial \bar{D}} \leq 0, \quad \frac{\partial H_{b}^{*}}{\partial \bar{D}} \leq 0, \quad \frac{\partial \hat{\alpha}_{z}}{\partial p_{D}} \leq 0, \quad \frac{\partial H_{b}^{*}}{\partial p_{D}} \leq 0, \text { with } z \in\{b m, g m\}
$$

For case (iii) the comparative statics from (i) and (ii) apply after switching indices $a$ and $b$.

Figure 1 illustrates the relationship between the minimum relative wage for labor market participation of $b$ and the required time $\bar{D}$ for different values of $\alpha$. The values on the vertical axis $(\bar{D}=0)$ refer to the required relative wage for $b$ to participate in the labor force if the couple has no children.

The theory presents a mechanism relating each partner's earnings potential and required child care to labor supply decisions in the household. Deciding which of the partners specializes in the labor market could be made either based on comparative advantage $(\lambda=0)$ or based on relative preferences for partner $b$ to specialize in household production $(\lambda>>0)$. In the data we observe that almost all male partners work full-time before as well as after migration. Female labor supply and labor market participation vary to a larger extent. Given our data the subsequent analysis is going to study the implications of the model for the case that households adjust female labor supply and the male partner works full time in the labor market. Hence, we refer to partner $a$ as 

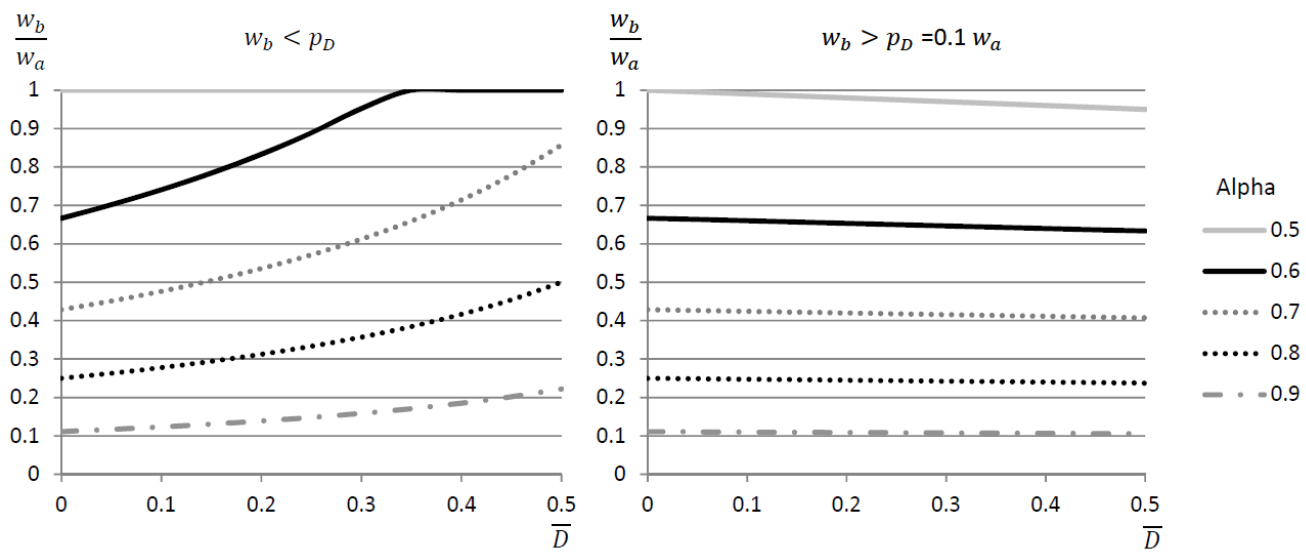

Figure 1: Required child care and minimum relative wage for labor force participation of partner $b$ under (i), in which $w_{a} \geq w_{b}$ and $w_{b}<p_{D}$, left panel, and under (ii) in which $w_{a} \geq w_{b} \geq p_{D}$, right panel.

the male and partner $b$ as the female partner and present the hypotheses referring to female labor force participation.

This paper focuses on labor supply decisions in the context of international migration. Migration goes along with changes in the partners' job opportunities. In the light of our theoretical model, we relate potential explanatory factors like the partners' education - as an indicator of their earnings potential - as well as family characteristics to household economies and labor supply abroad.

We can summarize the hypotheses we test as follows.

Hypothesis 1 (the effect of education). Female labor force participation is lowest if the male partner has a higher level of education.

Hypothesis 1 follows from our theoretical model if the partners' education levels are an indicator of their relative earnings potential in Denmark and abroad.

Hypothesis 2 (the tied mover effect). Female labor force participation is lower abroad if the female partner is a tied mover.

Hypothesis 2 follows as if a couple migrates mainly for job opportunities of one partner, then we expect by revealed preference argumentation that the wage rate of that partner increases. This, in turn, makes it likely that the other partner works less, even if the wage rate of the other partner 
would be the same abroad. If the wage rate of the accompanying spouse is lower abroad, this further reduces his or her expected labor force participation.

Hypothesis 3 (the effects of children). Having children, especially young children, reduces female labor force participation in countries with expensive child care services.

Hypothesis 3 follows from our model if the female partner is more often the one taking care of children at home, and child care costs in Denmark and other Nordic countries are heavily subsidized, while child care is rather expensive elsewhere. This suggests that having children reduces female labor force participation more strongly outside the Nordic countries. Figure 1 illustrates that the relative wage required for female labor force participation is higher if child care is provided by the female partner in the household.

Hypothesis 4 (cross-country differences). Female labor force participation rate is lower in countries with wider income differences.

According to our model, labor force participation rate of secondary earners (partner $b$ ) is decreasing in the wage rate of the primary earners (partner $a$ ). The cross-country differences in expected female labor force participation rates follow from combining the theoretical prediction of Hypothesis 2 with the previous empirical results on income differences between different countries and self-selection and sorting of emigrants.

Although Denmark has one of the highest female labor force participation rates, females more often work part-time compared to males (OECD 2015). In addition, in terms of hourly wages the OECD reports an unconditional gender pay gap for Denmark of $11.8 \%$ in $2010 .^{5}$ Thus, already before emigration in most couples the male partner earned more than the female and this gap is likely to increase abroad, in particular in destination countries with wider income differences. Income differences in the US and non-Western countries are larger than income differences in Australia, Canada, New Zealand and Western Europe; see Grogger and Hanson (2010) and Klugman (2011). Therefore, Hypothesis 4 can be tested by comparing female labor force participation rates in the US with female labor force participation rates in other Western countries.

\footnotetext{
${ }^{5}$ The unconditional gender pay gap is not to be interpreted as a measure for discrimination of women. It is the joint effect of differences in qualifications, career choices and any remaining discrimination. Time allocation which maximizes family resources for consumption depends on the unconditional pay gap.
} 
Borjas (1987) argues that emigrants from a country with a relatively narrow income distribution such as Denmark are selected from the upper end of that distribution because they are more likely to gain abroad compared to those at the lower end. Grogger and Hanson (2010) find that migrants self-select and sort into destination countries according to their returns to education. Borjas et al. (2015) show that Danes emigrating to other Nordic countries are not as strongly self-selected in terms of their earnings as Danes emigrating to the rest of the world. In the family context, Junge et al. (2014) find that emigrant couples from Denmark are strongly positively selected on the primary earner's income. They show that the self-selection of couples into migration is more responsive to the primary earner's income and less responsive to the secondary earner's income than the self-selection of singles with respect to their income.

An increase in earnings differentials between the partners in the country of residence might make it optimal to switch from a dual-earner to a single-earner model (implying typically a male breadwinner). Therefore, we expect labor force participation of tied movers to be highest in Nordic countries and lowest in the US and non-Western countries, with other Western countries having rates in between. A competing hypothesis could be that couples with a certain preference for division of labor, irrespective of economic incentives, self-select into particular destinations. A further alternative hypothesis unrelated to our model would link differences in female labor force participation among Danish emigrant women in different countries to differences in female labor force participation in those countries. We compare predictions arising from our model with these alternative hypotheses in section 5 .

Moreover, couples with children might not be able to find suitable and affordable child care opportunities abroad. If a couple has to take care of its children at home, the parent doing so, typically the mother, has less time available in the labor market. The threshold for female labor force participation increases and the female partner is more likely not to work. On the other hand, if child care is bought on the market the female is more likely to work. According to the presented theory the decision whether or not to purchase child care services depends on their price relative to the wage rate of the partner who specializes in home production. In Denmark and other Nordic countries, child care services are heavily subsidized and comparatively cheap. This allows both partners to combine work and family. For Sweden, Angelov et al. (2016) show that labor force participation rates of mothers are high, even though after parenthood the pay gap between partners increases among approximately $80 \%$ of households. In many other countries, child care is less easily available 
and more costly than in Denmark. ${ }^{6}$ Our prior is that female labor force participation decreases abroad if the couple has children, in particular for couples with children below school age, and that this relationship is less strong for the Nordic countries.

Although we presented our model in a unitary framework, it would be straightforward to extend it to a collective framework. Instead of maximizing household utility function, we would write the two partners' utility functions separately. When the household resource allocation is Pareto efficient, the bargaining outcome is as if the household would maximize the sum of the two partners' utility functions, weighted to reflect their relative bargaining power (Chiappori, 1988; Apps and Rees, 1988). Cherchye et al. (2012) extended the model to account for more than one domestic good (such as parental time and household activities such as cleaning), and brought the model to data. We use the simpler unitary model as our data does not allow testing the richer collective model. As Cherchye et al. (2012), we separate between time spent on child care and other household production, but our setting is simpler as we take the time required for child care as exogenous and do not model leisure choice. Instead, we allow child care to be produced either inside the household, or bought from the market, and show that the effects of time required for child care on female labor supply depend mainly on whether the child care cost is more or less than the female wage rate. As a result, female labor force participation is expected to be much lower among couples requiring child care in countries with more expensive child care, but not in the Nordic countries where public day care centers are available and affordable for most parents.

\section{Data}

We study emigration of couples using Danish administrative data which we link with own survey data. A first part of our analysis draws on full population administrative register data for migrants and non-migrants. Our main administrative data sources are the population register, education register, and migration register. Data from various administrative sources are combined using an anonymized social security number. By law, all residents in Denmark have to have a social security number which is necessary in everyday life, including opening a bank account, receiving wages and salaries or social assistance, visiting doctor or being registered at school. Using the social security number as identifier we link information from the different sources and generate a

\footnotetext{
${ }^{6}$ Previous literature has shown that the quality, availability and affordability of child care services has a considerable impact on couples' labor supply decisions. For example, Herbst (forthcoming) shows that receiving child care subsidies increased employment of mothers in the US.
} 
data set of couples with male and female partners cohabiting at the same address in a given year and pool the data for all years together. ${ }^{7}$ Danish residents are obliged by law to report emigration to the authorities in case they stay abroad for more than six months. Additionally, Danish tax laws provide incentives for migrants to register when they emigrate. From the migration register, we know the date of migration for each individual and the corresponding country of destination.

We consider emigration events between 1982 and 2002 and merge migration register information for each individual to the other administrative data from the year before. We define that a couple emigrates if both partners leave Denmark according to the administrative data within the same year to the same destination country. We restrict our sample to partners who are between 18 and 55 in the year of emigration, and are both Danish citizens, born in Denmark. The reason for this restriction is that in international couples, emigration from Denmark might imply returning to the home country of one partner, making a migration decision qualitatively different. Our analysis revealed that results on the subsample of individuals with a foreign partner are qualitatively similar but statistically weaker and thus will not be reported here. After the mentioned restrictions, we obtain an overall sample of 16,490,505 couple-year observations for the given years in Denmark, and 5,649 couples with both partners having emigrated within the same year to the same destination country and neither partner having returned to Denmark during the subsequent 5 years (Table 1). Among 3,257 of these emigrant couples neither partner returned until the end of 2007. Most of these couples (86.9\%) emigrated to another Western country. A clear majority migrated to a Western European country, including the other Nordic countries (24.5\%) and the UK (11.0\%) as major destinations. $11.0 \%$ of couples having not returned by the end of 2007 migrated to the US, and $8.4 \%$ to Australia, Canada or New Zealand. The destination country shares do not differ much between couples having stayed at least 5 years abroad and those having not returned until the end of 2007. Our analysis excludes couples migrating to Greenland or the Faroe Islands because these are autonomous territories of Denmark.

To study motivations to emigrate as well as the emigrant couples' labor force participation abroad we draw on unique survey data. The survey was conducted in 2008 among emigrants who had left Denmark in 1987, 1988, 1992, 1993, 1997, 1998, 2001 or 2002, and had not returned by the end of 2007. It was planned by Munk and Poutvaara within the project "Danes Abroad: Economic and Social Motivations for Emigration and Return Migration", financed by the Danish Council for

\footnotetext{
${ }^{7}$ Both married and cohabiting couples are included. Cohabitation before or instead of marriage is a common phenomenon in the Scandinavian countries (Kiernan, 2004).
} 


\begin{tabular}{lccc} 
& $\begin{array}{c}\text { Non- } \\
\text { migrant } \\
\text { couples }\end{array}$ & $\begin{array}{c}\text { Registered } \\
\text { joint couple } \\
\text { migrations, } \\
5+\text { years }\end{array}$ & $\begin{array}{c}\text { Registered } \\
\text { joint couple } \\
\text { migrations, } \\
\text { no return }\end{array}$ \\
\hline Nordic countries & - & $21.8 \%$ & $24.5 \%$ \\
United Kingdom & - & $11.7 \%$ & $11.0 \%$ \\
Rest of Western Europe & - & $33.8 \%$ & $32.1 \%$ \\
United States & - & $10.0 \%$ & $11.0 \%$ \\
AUS, CAN, NZ & - & $6.8 \%$ & $8.4 \%$ \\
Non-Western countries & - & $15.9 \%$ & $13.1 \%$ \\
& & \\
& & 5,649 & 3,257 \\
Observations (couple-year) & $16,490,505$ & \\
\hline Source: Register data. & \multicolumn{4}{l}{} \\
Notes: Initial destination countries reported (AUS: Australia, CAN: Canada, NZ: New Zealand). \\
Joint emigration according to the administrative data requires that both partners are Danish citizens, \\
born in Denmark, between 18 and 55 when emigrating and emigrated in the same year to the same \\
destination and did not return during the subsequent 5 years (column 2) or until the end of 2007 \\
(column 3).
\end{tabular}

Table 1: Descriptive statistics. Non-migrants and joint emigrations of couples according to register data 1982-2002.

Independent Research (Social Sciences) and carried out by Statistics Denmark. Statistics Denmark used the full population register to identify all Danish citizens who had emigrated, and had not returned by the end of 2007. Emigrants had to be aged 18 or more when they emigrated, and at most 59 in 2007. These restrictions yield a population of 17,309 emigrants during the selected years. For $55 \%$ of those emigrants Statistics Denmark found contact information on relatives living in Denmark. They were asked to provide address, telephone number and email address of the person abroad. Statistics Denmark then tried to contact the target persons using this information. The link to the web-based questionnaire was sent out by email to 6,984 emigrants with validated email addresses. When data collection was closed in August 2008 4,257 persons had answered the survey, making an overall response rate of $61 \%$.

We link respondents with the population register data using the unique personal identifier. Our survey data contains information on several characteristics such as education, household composition and work situation for the respondent and his or her partner before migration in Denmark as well as in 2008 abroad. Survey respondents were also asked about their main motivation to emigrate and their preferences for their own and for their partner's labor force participation. On top of this, they were asked to provide information about intra-household resource allocation before migration in Denmark and in 2008 abroad.

Subsequent analysis focuses on long-term emigration of couples. We consider only partners who stayed abroad at least until the end of 2007. First, we restrict the analysis to individuals who report 
to have emigrated with their partner and whose partner is a Danish citizen, born in Denmark. We also require that the partners lived together in Denmark. In our survey 632 respondents fulfill these restrictions. Using the administrative migration register we are able to construct the population of individuals who emigrated with their partner to the same destination country during the same years as those considered for the survey. Like for the partners in the survey we require that both partners are Danes, born in Denmark and did not return until the end of 2007. The administrative data yields an overall sample of 1250 couples in which partners were at least 18 when emigrating and at most 59 in 2007. The descriptive statistics for migrations from the administrative data and our survey are reported in columns 1 and 2 of Table 2 . Table 2 shows the distribution of initial destinations and emigration years for the two samples.

\begin{tabular}{|c|c|c|}
\hline & $\begin{array}{c}\text { Registered } \\
\text { joint couple migrations, } \\
\text { no return }\end{array}$ & $\begin{array}{l}\text { Survey respondents } \\
\text { joint emigration, } \\
\text { no return }\end{array}$ \\
\hline Nordic countries & $25.8 \%$ & $23.4 \%$ \\
\hline United Kingdom & $10.6 \%$ & $13.1 \%$ \\
\hline Rest of Western Europe & $29.7 \%$ & $30.2 \%$ \\
\hline United States & $11.0 \%$ & $14.1 \%$ \\
\hline AUS, CAN, NZ & $7.7 \%$ & $5.1 \%$ \\
\hline Non-Western countries & $15.2 \%$ & $14.1 \%$ \\
\hline $1987 / 88$ & $13.3 \%$ & $9.7 \%$ \\
\hline $1992 / 93$ & $11.8 \%$ & $14.6 \%$ \\
\hline $1997 / 98$ & $23.4 \%$ & $30.2 \%$ \\
\hline $2001 / 02$ & $51.5 \%$ & $45.5 \%$ \\
\hline Observations & 1,250 & 632 \\
\hline \multicolumn{3}{|c|}{$\begin{array}{l}\text { Sources: Survey and register data. } \\
\text { Notes: Initial destination countries and emigration years reported (AUS: Australia, CAN: Canada, } \\
\text { NZ: New Zealand). Joint emigration according to the administrative data requires that both partners } \\
\text { are Danish citizens, born in Denmark, at least } 18 \text { when emigrating and at most } 59 \text { in } 2007 \text { and } \\
\text { emigrated in the same year to the same destination and did not return until the end of } 2007 \text {. } \\
\text { According to survey data both partners are Danish citizens, born in Denmark, the respondent is at } \\
\text { least } 18 \text { when emigrating and at most } 59 \text { in } 2007 \text { and reported to have migrated together with the } \\
\text { partner. }\end{array}$} \\
\hline
\end{tabular}

Table 2: Descriptive statistics. Joint emigrations of couples in register data and survey.

Data indicates that a slightly lower share of survey respondents emigrated in 1987/88 compared with the emigrations in the administrative registers. Overall, the shares of migrant couples having emigrated in the different year-pairs is not very different between the two columns. The same holds for migration to different destination countries. ${ }^{8}$

Our final sample obeying the above restrictions consists of 522 respondents and their partners

\footnotetext{
${ }^{8}$ To account for a potential bias in our results due to sampling design or non-response in the survey we also run our main analysis for robustness with a weighted sample which is explained in more detail in Appendix C.
} 


\begin{tabular}{|c|c|c|c|}
\hline & Male respondents & Female respondents & All respondents \\
\hline Low power couples & $16.3 \%$ & $16.6 \%$ & $16.5 \%$ \\
\hline Female power couples & $8.6 \%$ & $11.9 \%$ & $10.2 \%$ \\
\hline Male power couples & $21.2 \%$ & $17.4 \%$ & $19.4 \%$ \\
\hline Power couples & $53.9 \%$ & $54.2 \%$ & $54.0 \%$ \\
\hline Nordic countries & $17.5 \%$ & $24.5 \%$ & $20.9 \%$ \\
\hline United Kingdom & $12.6 \%$ & $13.4 \%$ & $13.0 \%$ \\
\hline Rest of Western Europe & $32.7 \%$ & $30.8 \%$ & $31.8 \%$ \\
\hline United States & $15.6 \%$ & $16.6 \%$ & $16.1 \%$ \\
\hline AUS, CAN, NZ & $7.4 \%$ & $3.6 \%$ & $5.6 \%$ \\
\hline Non-Western countries & $14.1 \%$ & $11.1 \%$ & $12.6 \%$ \\
\hline No children in DK & $47.6 \%$ & $47.8 \%$ & $47.7 \%$ \\
\hline Youngest child $0-6$ in DK & $44.2 \%$ & $44.7 \%$ & $44.4 \%$ \\
\hline Youngest child $7+$ in DK & $8.2 \%$ & $7.5 \%$ & $7.9 \%$ \\
\hline No children in 2008 & $20.5 \%$ & $23.3 \%$ & $21.8 \%$ \\
\hline Youngest child $0-6$ in 2008 & $33.5 \%$ & $32.4 \%$ & $33.0 \%$ \\
\hline Youngest child $7+$ in 2008 & $46.0 \%$ & $44.3 \%$ & $45.2 \%$ \\
\hline Observations & 269 & 253 & 522 \\
\hline
\end{tabular}

Source: Survey and register data.

Note: Country of residence and all characteristics in 2008 according to survey data (DK: Denmark, AUS: Australia, CAN: Canada, NZ: New Zealand).

Table 3: Descriptive statistics for respondents having migrated with current partner.

who still live together in 2008 according to the survey data. The composition of this sample with respect to various characteristics is reported in Table 3. We did not ask the partner's gender in the survey, but asked whether the respondent was either married or in a registered partnership or cohabiting. We did not find any same-gender partnerships among our respondents according to the linked administrative data. Therefore subsequent analysis refers to partners as male and female. Following Costa and Kahn (2000) we distinguish different "power" types of couples reflecting the partners' levels of education. In power couples both partners have at least college education. In male and female power couples, only one partner holds a college degree and in low power couples neither partner has completed college education. ${ }^{9}$ With $54.0 \%$, power couples are the biggest group among the respondents while there are $19.4 \%$ male power couples and only $10.2 \%$ female power couples. The fraction of 25 to 64 year olds in the Danish population with at least college degree was $24 \%$ in 2008 (Statistics Denmark 2009). Thus compared with the overall Danish population the average level of education among our respondents is high. This is in line with results from Borjas et al. (2015) who find that emigrants from Denmark are strongly positively self-selected according to their pre-migration education. Junge et al. (2014) also show that power couples are more likely to emigrate from Denmark. Table 3 reports the country of residence of the respondents in 2008. A large fraction of respondents in our sample (20.9\%) live in one of the other Nordic countries,

\footnotetext{
${ }^{9}$ We define college degree as having at least medium tertiary education; however, our results are robust to using university bachelor's degree as cutoff.
} 
Sweden, Norway, Finland or Iceland. $16.1 \%$ live in the US, and $13.0 \%$ in the UK. In total $65.7 \%$ percent of the respondents report that they live in another Western European country. ${ }^{10} 52.3 \%$ of respondents had children in the household before emigration, $44.4 \%$ with the youngest child below school age and only $7.9 \%$ with the youngest child aged seven or older. In $2008,78.2 \%$ have children in the household, including $33.0 \%$ with children below school age and $45.2 \%$ with the youngest child aged seven or older. Characteristics presented in Table 3 do not reveal any response bias for whether the survey respondent was male or female, with the exception that there are slightly more female than male respondents in other Nordic destination countries. At the $5 \%$ significance level, this is the only statistically significant difference among the reported characteristics in Table 3. Using the identifier for cohabiting or married partners from the administrative population data we are able to identify 60 couples in which both partners answered the survey. Our results are robust to excluding either the female or the male respondents among these couples from the analysis.

\section{Big Picture}

\subsection{Labor Force Participation and Self-Selection into Emigration}

As dual-earner couples face a potentially difficult tradeoff in whose career to prioritize (Mincer 1978; Frank 1978), there are strong reasons to expect that single-earner couples are more likely to emigrate, in general. Furthermore, already Tiebout (1956) suggested that different policies might be important determinants of choices on where to live. In Denmark and other Nordic countries, generous provision of child care services makes it easier for couples to pursue a dual-earner model. High taxes at the individual level and relatively egalitarian wage structure also promote the dual-earner model, making it difficult to make the ends meet in families with a single earner. Therefore, it could be that couples preferring a traditional male breadwinner model would selfselect into emigration into countries with less egalitarian wage structure and less generous child care services. Together, these insights from labor economics and public economics suggest a similar pattern: couples in which both partners work should be less likely to emigrate, especially outside other Nordic countries. To test this prediction empirically, we use the full population data comparing labor force participation between couples that emigrate and those that stay in Denmark.

\footnotetext{
${ }^{10}$ There are some cases for which the initial emigration country differs from the country of residence in 2008 because couples migrated onwards to another country. Due to small numbers of observations in the survey data subsequent analysis groups together other Western destination countries apart from the US and the Nordic countries in one category. We show in Appendix B that the findings we describe later do not differ much between the destination groups Australia, Canada and New Zealand, the UK and other Western European countries.
} 
Male Female

\begin{tabular}{lcccc} 
& $\begin{array}{c}\text { Both } \\
\text { in labor force }\end{array}$ & $\begin{array}{c}\text { in the labor force, } \\
\text { female at home }\end{array}$ & $\begin{array}{c}\text { in the labor force, } \\
\text { male at home }\end{array}$ & $\begin{array}{c}\text { At least one partner } \\
\text { retiree or student }\end{array}$ \\
\hline Non-migrants & $87.1 \%$ & $5.8 \%$ & $1.0 \%$ & $6.1 \%$ \\
Migrants & $79.1 \%$ & $10.0 \%$ & $3.1 \%$ & $7.7 \%$ \\
Nordic countries & $77.6 \%$ & $9.2 \%$ & $4.2 \%$ & $9.1 \%$ \\
Non-Nordic countries & $79.2 \%$ & $10.3 \%$ & $2.7 \%$ & $7.8 \%$ \\
United States & $77.6 \%$ & $11.6 \%$ & $2.8 \%$ & $9.1 \%$ \\
Other Western countries & $80.2 \%$ & $10.0 \%$ & $2.7 \%$ & $7.2 \%$ \\
Non-Western countries & $79.9 \%$ & $10.2 \%$ & $3.5 \%$ & $6.5 \%$ \\
\hline
\end{tabular}

Source: Register data.

Notes: No. of non-migrant couple-year observations: 16,490,505, no. of migrant observations: 3,257

as shown in Table 1. Initial destination country according to register data. Out of labor force excludes retirees and students.

Table 4: Labor force participation in Denmark.

Table 4 refers to the sample described in the previous section with 16,490,505 non-migrant coupleyear observations and 3,257 migrant couples in which neither partner had returned to Denmark until the end of 2007. In $87.1 \%$ of all non-migrant couples both partners participate in the labor force in Denmark. With $79.1 \%$ this fraction is lower among migrant couples. The share in which the female partner participates and the male partner does not participate in the labor force is only 1.0\% among non-migrant and 3.1\% among migrant couples (excluding retirees or students). On the other hand, the female partner is out of the labor force while the male partner participates in the labor force among $5.8 \%$ of non-migrant and $10.0 \%$ of migrant couples. Moreover, Table 4 indicates that the share of females out of the labor force while the male partner participates in the labor force is highest among couples emigrating to the US, although the difference is small. The share of male partners out of the labor force while the female participates in the labor force is highest among couples migrating to one of the other Nordic countries. Table B1 in the Appendix presents labor force participation of the partners among migrants and non-migrants for couples in which the female partner is below 35 and those in which the female partner is 35 or older. ${ }^{11}$ Results suggest that selection and sorting of migrants to the different destination country groups is slightly stronger in the subsample in which the female is 35 or older. In general, we find that couples in which both partners are in the labor force are less likely to emigrate, but overall we do not find strong evidence for sorting into different destinations in terms of pre-migration differences in labor force participation: the differences in female labor force participation rates before emigration between couples subsequently migrating to different destination countries are small. Statistical inference is going to be conducted in the following section using regression analysis.

\footnotetext{
${ }^{11}$ Among migrant couples the median age for the female partner is 35.
} 


\subsection{Main Motivation to Emigrate}

Our survey provides information about the respondents' main motivation to emigrate. Table 5 presents information separately for men and women who emigrated with a Danish partner and live together abroad in 2008. For all residence country groups, own work was the most important motivation to emigrate for a clear majority of male partners. The majority of female partners in all non-Nordic countries migrated due to family reasons. Work reasons dominate among male and family reasons among female partners, especially among those in the US and in non-Western countries. Among female partners who live in other Nordic countries, about one third emigrated for work, almost one third for family and a little more than one third for other reasons, such as studies.

\begin{tabular}{lccccc} 
& $\begin{array}{c}\text { Nordic } \\
\text { countries }\end{array}$ & $\begin{array}{c}\text { United } \\
\text { States }\end{array}$ & $\begin{array}{c}\text { Other } \\
\text { Western } \\
\text { countries }\end{array}$ & $\begin{array}{c}\text { Non- } \\
\text { Western } \\
\text { countries }\end{array}$ & Total \\
\hline Male respondents & & & & & \\
Own work & $66.0 \%$ & $81.0 \%$ & $71.1 \%$ & $92.1 \%$ & $74.7 \%$ \\
Family & $10.6 \%$ & $0.0 \%$ & $7.8 \%$ & $0.0 \%$ & $6.0 \%$ \\
Other reasons & $23.4 \%$ & $19.0 \%$ & $21.1 \%$ & $7.9 \%$ & $19.3 \%$ \\
\hline Female respondents & & & & & \\
Own work & $33.9 \%$ & $11.9 \%$ & $20.7 \%$ & $14.2 \%$ & $21.7 \%$ \\
Family & $30.7 \%$ & $76.2 \%$ & $52.9 \%$ & $67.9 \%$ & $53.0 \%$ \\
Other reasons & $35.4 \%$ & $11.9 \%$ & $26.4 \%$ & $17.9 \%$ & $25.3 \%$ \\
\hline Source: Survey data. & & & & & \\
$\quad$ Note: No. of observations: 269 male and 253 female respondents. Distribu- \\
$\quad$ tion according to destinations as shown in Table 3.
\end{tabular}

Table 5: Main motivations to emigrate.

Table 6 presents evaluations of further factors which had an impact on the decision to emigrate. Two out of five female partners living outside Nordic countries viewed a less stressful working life as an important or very important reason to emigrate, and one in ten as an argument for staying in Denmark. Among male partners migrating outside other Nordic countries, a less stressful working life was more often an argument for staying in Denmark. Both males and females living with their partner in one of the other Nordic countries view a less stressful working life more often as an argument for emigration.

Furthermore, the distribution of preferences in Table 6 suggests that most parents viewed considerations related to their children to be neither in favor nor against emigration, but there is also a significant minority which saw considerations related to children as an important or very important reason to emigrate. This is most pronounced among parents migrating to the US. Havnes and Mogstad (2015) show for Norway that universal public child care is most beneficial for children from disadvantaged family backgrounds. They find negative effects on child outcomes for families 


\begin{tabular}{llccccc} 
& & & & Other & Non- \\
& & $\begin{array}{c}\text { Nordic } \\
\text { countries }\end{array}$ & $\begin{array}{c}\text { United } \\
\text { States }\end{array}$ & $\begin{array}{c}\text { Western } \\
\text { countries }\end{array}$ & $\begin{array}{c}\text { Western } \\
\text { countries }\end{array}$ & Total \\
\hline Male respondents & & & & & & \\
Less stressful working life & in favor & $25.5 \%$ & $14.3 \%$ & $21.8 \%$ & $15.8 \%$ & $20.0 \%$ \\
& against & $4.3 \%$ & $28.6 \%$ & $23.2 \%$ & $31.6 \%$ & $22.6 \%$ \\
Considerations for children & in favor & $6.4 \%$ & $26.2 \%$ & $16.2 \%$ & $23.7 \%$ & 17.8 \\
(couples with children) & against & $2.1 \%$ & $2.4 \%$ & $3.5 \%$ & $0.0 \%$ & $2.4 \%$ \\
\hline Female respondents & & & & & & \\
Less stressful working life & in favor & $19.4 \%$ & $42.9 \%$ & $36.4 \%$ & $46.4 \%$ & 34.8 \\
& against & $4.8 \%$ & $11.9 \%$ & $7.4 \%$ & $10.7 \%$ & $8.0 \%$ \\
Considerations for children & in favor & $11.3 \%$ & $31.0 \%$ & $19.8 \%$ & $14.3 \%$ & $19.2 \%$ \\
(couples with children) & against & $4.8 \%$ & $2.4 \%$ & $1.7 \%$ & $0.0 \%$ & $2.4 \%$ \\
\hline Source: Survey data. & & & & & &
\end{tabular}

Source: Survey data.

Note: No. of observations: 269 male and 253 female respondents. Distribution according to destinations as shown in Table 3.

Table 6: Selected arguments in favor or against emigration.

from the upper part of the earnings distribution. As Denmark is very similar to Norway in many respects, one could expect that potential negative effects of public child care are more pronounced among the group of emigrants whose average educational attainment is much higher compared to the overall population. ${ }^{12}$ Therefore, respondents for whom considerations related to children are a reason to emigrate might prefer that the children are taken care of at home, typically by the mother. Del Boca et al. (2014) find that parents' time spent with their child is important for the child's cognitive development. We also checked whether fertility decisions of the couples differ according to the country of residence but we did not find any systematic difference.

Our data also enable us to address the question which partner had stronger preferences towards emigration. Respondents were asked whether both had equally strong migration preferences, whether one of the partners was more in favor of emigration, or if either partner would have preferred not to migrate. Table 7 shows that in most cases the partners agreed on emigration and in a clear majority emigration was a joint preference of both partners. ${ }^{13}$ In every destination country group more than $50 \%$ of the respondents stated that they and their partner had equally strong preferences to emigrate. In $39.0 \%$ of couples, the male and in $9.1 \%$ the female partner was more strongly or even the only one in favor of emigration. In particular, in the non-Nordic countries, a larger share

\footnotetext{
${ }^{12}$ Baker et al. (2008) also find that universal child care programs might affect child outcomes negatively. Kottelenberg and Lehrer (2014) provide evidence that the effects of universal childcare depend strongly on the child's age. The negative effect is stronger when the children gain access at younger age, but turns positive for those that are 3 years or older.

${ }^{13} \mathrm{~A}$ potential concern in Table 7 might be a bias due to misreporting of the partner's preference depending on the characteristics of the partner who answered the questionnaire. Using the administrative data, we were able to identify 60 couples in which both the male and the female answered our survey and analyzed both partners' mutual assessment of migration preferences in this subsample. Table B2 shows that in $81.7 \%$ of the cases the partners' answers on their respective migration preferences were perfect matches. If there were deviations one partner mostly reported equal preferences while the other stated stronger migration preferences of the male or female partner. Thus, we can expect joint migration preferences to be correctly assessed by one partner for most of the remaining observations in our sample.
} 
of males had stronger emigration preferences reflecting migration due to male job opportunities as described above. The share of stronger female preferences towards emigration was highest among couples in the Nordic countries. If there was disagreement concerning the emigration decision it was mostly the female partner who disagreed: with $11.0 \%$ this share is highest among couples having emigrated to the US.

\begin{tabular}{lccccc} 
& Nordic & Other & Non- & \\
& Countries & States & $\begin{array}{c}\text { Western } \\
\text { countries }\end{array}$ & $\begin{array}{c}\text { Western } \\
\text { countries }\end{array}$ & Total \\
\hline Equal preferences & $53.2 \%$ & $51.2 \%$ & $51.9 \%$ & $51.5 \%$ & $52.0 \%$ \\
Stronger male preference & $27.5 \%$ & $34.2 \%$ & $34.4 \%$ & $31.8 \%$ & $32.6 \%$ \\
Stronger female preference & $13.8 \%$ & $3.7 \%$ & $6.9 \%$ & $12.1 \%$ & $8.5 \%$ \\
Female against emigration & $4.6 \%$ & $11.0 \%$ & $6.1 \%$ & $4.6 \%$ & $6.4 \%$ \\
Male against emigration & $0.9 \%$ & $0.0 \%$ & $0.8 \%$ & $0.0 \%$ & $0.6 \%$ \\
\hline Source: Survey data. & \\
$\quad$ Note: No. of observations: 522 respondents. Distribution according to destinations as shown \\
in Table 3.
\end{tabular}

Table 7: Partners' agreement or disagreement on emigration.

Overall, Tables 5 to 7 show that migration was a joint preference of both partners for most of the respondents, even though the migration motives differ: males migrated mainly for job opportunities and females for family reasons.

\subsection{Actual and Preferred Labor Force Participation}

Table 8 shows that the heterogeneity in migration motives is reflected strongly in differences in female labor force participation at different destinations. However, in Denmark the partners' labor force participation rates before migration do not differ much between couples living subsequently in different countries. ${ }^{14}$ Overall, in only $3.4 \%$ of the couples the female partner stayed at home while the male partner was in the labor force. There was no male partner who stayed at home while the female was in the labor force. We observe substantially lower female labor force participation abroad: in $28.2 \%$ of the couples the female partner stays at home and the male partner participates in the labor force. On the other hand, the share of couples abroad in which the female works and the male stays at home is only $1.0 \%$.

Low female labor force participation abroad is most pronounced among male power couples. This is in line with Hypothesis 1 from our model. The data reveal substantial differences in labor force

\footnotetext{
${ }^{14}$ We consider a partner as being in the labor force at a given time in case of employment, self-employment or unemployment. Couples with at least one student or retiree are reported in a separate category. There are $13.4 \%$ of couples with at least one student or retiree before emigration. Apart from one retiree in our sample this share is due to studies before migration.
} 


\begin{tabular}{|c|c|c|c|c|}
\hline & $\begin{array}{l}\text { Both in the } \\
\text { labor force }\end{array}$ & $\begin{array}{c}\text { Male in the } \\
\text { labor force, } \\
\text { female at home }\end{array}$ & $\begin{array}{l}\text { Female in the } \\
\text { labor force, } \\
\text { male at home }\end{array}$ & $\begin{array}{l}\text { At least one partner } \\
\text { retiree or student }\end{array}$ \\
\hline In Denmark & $83.1 \%$ & $3.4 \%$ & $0.0 \%$ & $13.4 \%$ \\
\hline Nordic countries & $78.0 \%$ & $4.6 \%$ & $0.0 \%$ & $17.4 \%$ \\
\hline Non-Nordic countries & $84.5 \%$ & $3.2 \%$ & $0.0 \%$ & $12.4 \%$ \\
\hline United States & $85.7 \%$ & $4.8 \%$ & $0.0 \%$ & $9.5 \%$ \\
\hline Other Western countries & $84.4 \%$ & $2.7 \%$ & $0.0 \%$ & $12.9 \%$ \\
\hline Non-Western countries & $83.3 \%$ & $3.1 \%$ & $0.0 \%$ & $13.6 \%$ \\
\hline Abroad in 2008 & $66.3 \%$ & $28.2 \%$ & $1.0 \%$ & $4.6 \%$ \\
\hline Low power couples & $69.8 \%$ & $24.4 \%$ & $3.5 \%$ & $2.3 \%$ \\
\hline Female power couples & $69.8 \%$ & $18.9 \%$ & $3.8 \%$ & $7.5 \%$ \\
\hline Male power couples & $50.5 \%$ & $43.6 \%$ & $0.0 \%$ & $5.9 \%$ \\
\hline Power couples & $70.2 \%$ & $25.5 \%$ & $0.0 \%$ & $4.3 \%$ \\
\hline Nordic countries & $87.2 \%$ & $5.5 \%$ & $1.8 \%$ & $5.5 \%$ \\
\hline Non-Nordic countries & $60.8 \%$ & $34.1 \%$ & $0.7 \%$ & $4.4 \%$ \\
\hline United States & $48.8 \%$ & $47.6 \%$ & $0.0 \%$ & $3.6 \%$ \\
\hline Other Western countries & $67.7 \%$ & $27.0 \%$ & $0.8 \%$ & $4.6 \%$ \\
\hline Non-Western countries & $48.5 \%$ & $45.5 \%$ & $1.5 \%$ & $4.6 \%$ \\
\hline No children in 2008 & $79.8 \%$ & $12.3 \%$ & $1.8 \%$ & $6.1 \%$ \\
\hline Youngest child $0-6$ in 2008 & $57.0 \%$ & $39.5 \%$ & $0.6 \%$ & $2.9 \%$ \\
\hline Youngest child $7+$ in 2008 & $66.5 \%$ & $27.5 \%$ & $0.9 \%$ & $5.1 \%$ \\
\hline
\end{tabular}

Sources: Survey data.

Note: No. of observations as shown in Table 3.

Table 8: Percentage shares for actual labor force participation.

\begin{tabular}{|c|c|c|c|c|c|}
\hline & $\begin{array}{l}\text { Both in the } \\
\text { labor force }\end{array}$ & $\begin{array}{c}\text { Male in the } \\
\text { labor force, } \\
\text { female at home }\end{array}$ & $\begin{array}{l}\text { Female in the } \\
\text { labor force, } \\
\text { male at home }\end{array}$ & $\begin{array}{c}\text { Both } \\
\text { at home }\end{array}$ & No answer \\
\hline All & 62.1 & 27.6 & 1.1 & 1.7 & 7.5 \\
\hline Nordic countries & $80.7 \%$ & $6.3 \%$ & $1.8 \%$ & $2.8 \%$ & $8.2 \%$ \\
\hline Non-Nordic countries & $57.1 \%$ & $33.2 \%$ & $1.0 \%$ & $1.5 \%$ & $7.3 \%$ \\
\hline United States & $40.5 \%$ & $52.4 \%$ & $1.2 \%$ & $0.0 \%$ & $6.0 \%$ \\
\hline Other Western countries & $62.7 \%$ & $28.1 \%$ & $0.8 \%$ & $2.3 \%$ & $6.1 \%$ \\
\hline Non-Western countries & $56.1 \%$ & $28.8 \%$ & $1.5 \%$ & $0.0 \%$ & $13.6 \%$ \\
\hline
\end{tabular}

Source: Survey data.

Note: No. of observations as shown in Table 3.

Table 9: Percentage shares for preferred labor force participation. 
participation in 2008 depending on the country of residence. Female labor force participation rates are particularly low and decreased dramatically among couples having migrated to the US and to non-Western countries; in $47.6 \%$ of the couples in the US and in $45.5 \%$ of the couples in the non-Western countries the female stays out of the labor force while the male is in the labor force. In the Nordic countries, on the other hand, this is only the case among $5.5 \%$ of the couples. The corresponding share is $27.0 \%$ in other Western countries. Appendix Table B3 illustrates that female labor force participation between the UK, other Western European countries and Australia, Canada and New Zealand do not differ much. A high share of dual-earner couples in Australia, Canada and New Zealand compared with the US highlights that low female labor force participation is not driven by long distance migration. Table 8 additionally shows that female labor force participation decreased particularly among couples with children in the household.

Respondents were asked about their preferred division of labor in the household. In their answers they could indicate who of the partners they prefer to participate in the labor market. ${ }^{15}$ Table 9 reveals that low female labor force participation in 2008 seems to reflect the respondents' preferences towards their own and their partners' participation in the labor market. More than half of the respondents who reside in the US state that they prefer the male partner to work while the female partner stays at home. In the Nordic countries, on the other hand, most respondents prefer a dual-earner model. The share of respondents preferring a dual-earner model in the other Western countries is lower than among those in the other Nordic countries, but higher than among those in the US and the non-Western countries. ${ }^{16}$

Table B5 also provides insights about how the partners organize their household economy and who of them contributes more financially. We asked respondents whether they had separate economies or joint economies before migration as well as at the time of the survey in 2008. In separate economies the partners dispose of their own incomes and share only common expenses while couples with joint economies pool at least part of their individual incomes. Table B5 shows that, as a result of reduced female labor force participation, couples increasingly pool their earnings: the share of couples with separate economies declined from $12.6 \%$ before migration to $2.5 \%$ abroad, and the share of couples in which the male brings in all the money increased from $3.1 \%$ to $24.3 \%$.

\footnotetext{
${ }^{15}$ To alleviate the concern that respondents gave self-serving answers concerning their partner's preferred labor force participation we analyze responses among the 60 couples in which both the male and the female answered our survey. The responses are in most cases mutually consistent among both partners as Table B2 shows. Given this subsample of couples we are confident that the responses do not depend on which of the partners answered the survey. In a clear majority of cases, the partners agreed that either both should work, or that the male should work and female should stay at home.

${ }^{16}$ Appendix Table B4 also illustrates that female labor force participation preferences between the UK, other Western European countries and Australia, Canada and New Zealand do not differ much.
} 
This pattern is particularly strong among couples having emigrated to the non-Nordic countries indicating that intra-family income transfers compensating the female partner are more frequent. ${ }^{17}$

Table 9 shows that respondents in our sample have very different preferences for the partners' division of labor in different countries of residence. These are very similar to the differences in actually observed labor force participation. Moreover, analysis of administrative data showed that female labor force participation rates were higher among non-migrant couples than for migrant couples before emigration. Female labor force participation was lowest among couples migrating to the US in the subsequent year. Even though, these findings provide evidence for self-selection into destination countries according to a couple's division of labor, the observed decrease in female labor force participation rate is striking given that the dual-earner model was predominant in Denmark also among couples that subsequently emigrated.

\subsection{Tied Mover Effect}

\begin{tabular}{lcccc} 
A: All couples. & $\begin{array}{c}\text { Nordic } \\
\text { countries }\end{array}$ & US & $\begin{array}{c}\text { Other Western } \\
\text { countries }\end{array}$ & $\begin{array}{c}\text { Non Western } \\
\text { countries }\end{array}$ \\
\hline Male tied mover & $100.0 \%$ & $40.0 \%$ & $94.0 \%$ & $75.0 \%$ \\
& $(26)$ & $(5)$ & $(36)$ & $(4)$ \\
No tied mover & $97.0 \%$ & $46.1 \%$ & $75.8 \%$ & $62.5 \%$ \\
& $(33)$ & $(13)$ & $(62)$ & $(8)$ \\
Female tied mover & $90.0 \%$ & $54.5 \%$ & $65.4 \%$ & $51.9 \%$ \\
& $(50)$ & $(66)$ & $(165)$ & $(54)$ \\
B: Couples without & & & & \\
pre-school age children. & & & & \\
Male tied mover & $100.0 \%$ & $100.0 \%$ & $100.0 \%$ & $100.0 \%$ \\
& $(14)$ & $(2)$ & $(25)$ & $(1)$ \\
No tied mover & $100.0 \%$ & $57.1 \%$ & $86.9 \%$ & $80.0 \%$ \\
& $(21)$ & $(7)$ & $(46)$ & $(5)$ \\
Female tied mover & $90.9 \%$ & $59.1 \%$ & $66.4 \%$ & $66.7 \%$ \\
& $(33)$ & $(44)$ & $(116)$ & $(36)$ \\
\hline
\end{tabular}

Source: Survey data.

Notes: Numbers of observation in parentheses.

Table 10: Tied mover status and female labor force participation rates in percent.

In Table 10, we compare female labor force participation rates according to whether the female partner was a tied mover. We derive this information from the respondents' main motivation to

\footnotetext{
${ }^{17}$ A potential concern related to our results might be that household economy dynamics are driven by a time effect which is unrelated to migration. Moreover, the composition of emigrant cohorts might have changed over time. Our findings could then be driven by a subgroup of households in our sample depending on the year of emigration. Table B6 and B7 address these issues and alleviate our concerns: we present separately the household economies for couples that emigrated before 1999 and in 2001/2002. We do not observe qualitative differences between the cohorts in terms of changes in household economies. For example, the decrease in the share of separate household economies among the 2000/2001 emigration cohorts is almost as high as for the couples that left Denmark in earlier years. Moreover, the composition of the cohorts in terms of countries of residence does not vary substantially over the years of emigration either as Table B7 shows.
} 
emigrate. In all country groups, except for the US, female labor force participation is lowest when the female is a tied mover, i.e. male respondents reported that they migrated for their own job opportunities and female respondents reported to have migrated mainly for family reasons. At the same time, female labor force participation is highest among couples in which the male partner is a tied mover. Among couples without pre-school age children, we find that in all considered country groups all women whose male partner is a tied mover participate in the labor force. These findings support Hypothesis 2 in our model. A tied mover's partner should gain from migration, suggesting that wage differences abroad are larger than in Denmark. This makes it more likely that the tied mover (typically the female partner) works less, particularly if the couple migrates to a country where the dispersion of income is larger. This leads to lower female labor force participation, especially in the US and non-Western countries where incomes are more dispersed, and less so in other Nordic countries. ${ }^{18}$ Table B8 in the Appendix shows that the pattern presented for the aggregated group of other Western countries hold separately for the UK, Other Western Europe and Australia, Canada and New Zealand.

\section{Econometric Analysis}

\subsection{Self-Selection and Sorting of Emigrant Couples and the Dual-Earner Model}

We analyze self-selection and sorting of emigrant couples between 1982 and 2002. For each year we include couples where both partners were at least 18 and at most 55 . Table 11 presents OLS regression estimates for the self-selection of emigrant couples from the population of married or cohabiting Danes. We exclude those in which either partner is a retiree or student. The dependent variable is equal to one if both partners emigrate in the same year to the same destination country. We require that neither partner returns to Denmark in the following calendar year in columns 1 and 2. In columns 3 and 4 neither partner has returned to Denmark in the subsequent 5 years after emigration and in columns 5 and 6 we require that both stayed abroad at least until the end of 2007. We include dummy variables for different power types, the reference category being low power couples in which neither partner holds a college degree. Male power couples and power couples are most likely to emigrate. The probability to emigrate is lowest for low power couples. Having children is associated with statistically significantly lower emigration propensities. We in-

\footnotetext{
${ }^{18}$ According to Klugman (2011) the income GINI coefficient or the income quintile ratio $2000-2011$ is lowest in Nordic countries. For the US the income inequality measures are higher than for Western Europe and Australia, Canada and New Zealand.
} 
clude regressors for both partners' labor force status before emigration. Being out of labor force for the female as well as for the male partner goes along with a higher joint emigration probability. This confirms results presented in Table 4, which already revealed that the share of females as well as males out of labor force is higher among couples that subsequently migrate. However, the absolute number of couples in which the male partner is out of labor force is considerably lower. The results presented in Table 11 are robust to varying the restrictions on the minimum time both partners stay abroad. As additional robustness analysis we estimated the presented regression specifications separately by age group. Results revealed that estimates for power types, children in the family and labor force participation are robust to variations in the age restrictions.

\begin{tabular}{|c|c|c|c|c|c|c|}
\hline & \multicolumn{2}{|c|}{$\begin{array}{l}\text { Migrant couples } \\
\text { abroad } 1+\text { years }\end{array}$} & \multicolumn{2}{|c|}{$\begin{array}{l}\text { Migrant couples } \\
\text { abroad } 5+\text { years }\end{array}$} & \multicolumn{2}{|c|}{$\begin{array}{c}\text { Migrant couples } \\
\text { abroad until } 2007\end{array}$} \\
\hline $\begin{array}{l}\text { Power } \\
\text { couple }\end{array}$ & $\begin{array}{c}0.00259^{* * *} \\
(0.00005)\end{array}$ & $\begin{array}{c}0.00263^{* * *} \\
(0.00005)\end{array}$ & $\begin{array}{c}0.00057^{* * *} \\
(0.00002)\end{array}$ & $\begin{array}{c}0.00059^{* * *} \\
(0.00002)\end{array}$ & $\begin{array}{c}0.00062^{* * *} \\
(0.00003)\end{array}$ & $\begin{array}{c}0.00064^{* * *} \\
(0.00003)\end{array}$ \\
\hline $\begin{array}{l}\text { Female } \\
\text { power c. }\end{array}$ & $\begin{array}{c}0.00050^{* * *} \\
(0.00003)\end{array}$ & $\begin{array}{c}0.00053^{* * *} \\
(0.00003)\end{array}$ & $\begin{array}{c}0.00009 * * * \\
(0.00002)\end{array}$ & $\begin{array}{c}0.00010^{* * *} \\
(0.00002)\end{array}$ & $\begin{array}{c}0.00009^{* * *} \\
(0.00002)\end{array}$ & $\begin{array}{c}0.00009 * * * \\
(0.00002)\end{array}$ \\
\hline $\begin{array}{l}\text { Male } \\
\text { power c. }\end{array}$ & $\begin{array}{c}0.00268^{* * *} \\
(0.00005)\end{array}$ & $\begin{array}{c}0.00268^{* * *} \\
(0.00005)\end{array}$ & $\begin{array}{c}0.00074^{* * *} \\
(0.00003)\end{array}$ & $\begin{array}{c}0.00075^{* * *} \\
(0.00003)\end{array}$ & $\begin{array}{c}0.00077^{* * *} \\
(0.00003)\end{array}$ & $\begin{array}{c}0.00078^{* * *} \\
(0.00003)\end{array}$ \\
\hline $\begin{array}{l}\text { Male out } \\
\text { of LF }\end{array}$ & & $\begin{array}{c}0.00195^{* * *} \\
(0.00013)\end{array}$ & & $\begin{array}{c}0.00096 * * * \\
(0.00008)\end{array}$ & & $\begin{array}{c}0.00102^{* * *} \\
(0.00010)\end{array}$ \\
\hline $\begin{array}{l}\text { Female out } \\
\text { of LF }\end{array}$ & & $\begin{array}{c}0.00099^{* * *} \\
(0.00005)\end{array}$ & & $\begin{array}{c}0.00043^{* * *} \\
(0.00003)\end{array}$ & & $\begin{array}{c}0.00046^{* * * *} \\
(0.00004)\end{array}$ \\
\hline $\begin{array}{l}\text { Youngest } \\
\text { child } 0-6\end{array}$ & $\begin{array}{c}-0.00045^{* * *} \\
(0.00003)\end{array}$ & $\begin{array}{c}-0.00051^{* * *} \\
(0.00003)\end{array}$ & $\begin{array}{c}-0.00017^{* * *} \\
(0.00002)\end{array}$ & $\begin{array}{c}-0.00019^{* * *} \\
(0.00002)\end{array}$ & $\begin{array}{c}-0.00019^{* * *} \\
(0.00002)\end{array}$ & $\begin{array}{c}-0.00022^{* * *} \\
(0.00002)\end{array}$ \\
\hline $\begin{array}{l}\text { Youngest } \\
\text { child } 7+\end{array}$ & $\begin{array}{c}-0.00059 * * * \\
(0.00002)\end{array}$ & $\begin{array}{c}-0.00063^{* * *} \\
(0.00002)\end{array}$ & $\begin{array}{c}-0.00021^{* * *} \\
(0.00001)\end{array}$ & $\begin{array}{c}-0.00022^{* * *} \\
(0.00001)\end{array}$ & $\begin{array}{c}-0.00023^{* * *} \\
(0.00001)\end{array}$ & $\begin{array}{c}-0.00024^{* * *} \\
(0.00001)\end{array}$ \\
\hline Constant & $\begin{array}{c}0.00013 \\
(0.00021)\end{array}$ & $\begin{array}{r}-0.00035^{*} \\
(0.00020)\end{array}$ & $\begin{array}{c}0.00013 \\
(0.00013)\end{array}$ & $\begin{array}{c}-0.00016^{* * *} \\
(0.00004)\end{array}$ & $\begin{array}{c}0.00016^{* * *} \\
(0.00008)\end{array}$ & $\begin{array}{c}0.00020^{* * *} \\
(0.00006)\end{array}$ \\
\hline R-squared & $\begin{array}{c}0.001 \\
15.351211\end{array}$ & $\begin{array}{l}0.001 \\
15.351211\end{array}$ & $\begin{array}{c}0.000 \\
15.343786\end{array}$ & $\begin{array}{c}0.000 \\
15.343786\end{array}$ & $\begin{array}{c}0.000 \\
15.341536\end{array}$ & $\begin{array}{c}0.000 \\
15.341 .536\end{array}$ \\
\hline Observations & $15,351,211$ & $15,351,211$ & $15,345,180$ & $15,343,180$ & $10,341,030$ & $15,341,030$ \\
\hline $\begin{array}{l}\text { Notes: OLS e } \\
\text { Dummies for } \\
* * * \text { Significan } \\
* * \text { Significant } \\
* \text { Significant }\end{array}$ & $\begin{array}{l}\text { data. } \\
\text { nation. St } \\
\text { nale age, } \mathrm{m} \\
\text { t the } 1 \text { per } \\
\text { the } 5 \text { perc }\end{array}$ & $\begin{array}{l}\text { ard errors } \\
\text { age and ca } \\
\text { t level. } \\
\text { level. } \\
\text { level. }\end{array}$ & $\begin{array}{l}\text { rentheses } \\
\text { ar year in }\end{array}$ & $\begin{array}{l}\text { terd at ho } \\
\text { ed; notatic }\end{array}$ & $\begin{array}{l}\text { old level. } \\
\mathrm{F}=\text { labor for }\end{array}$ & \\
\hline
\end{tabular}

Table 11: Linear probability regressions: Joint emigration of partners from Denmark, 1982-2002.

Results presented above revealed that female labor force participation is already lower in Denmark among migrant couples compared to non-migrant couples. Table 12 now shows how female labor force participation in Denmark is related to observable characteristics among non-migrant 
and migrant couples when estimating a linear probability model on the administrative data. We restrict attention to female labor force participation as this is the relevant margin in our empirical setting. ${ }^{19}$ We do not observe large differences between the coefficient estimates for the sample of non-migrant couples and migrant couples with different minimum durations of stay abroad. We include the couple's power type (reference category: low power couples) and indicator variables for children in the household as explanatory variables. Females in power couples and in female power couples are more likely to participate in the labor market than females in low power couples. A youngest child below the age of seven is associated with reduced female labor force participation. However, the magnitude of the coefficient estimate suggests a reduction of female labor force participation of only around 4 to $5 \%$ in case a couple has young children.

\begin{tabular}{lcccc} 
& Non-migrant couples & $\begin{array}{c}\text { Migrant couples } \\
\text { abroad 1+ years }\end{array}$ & $\begin{array}{c}\text { Migrant couples } \\
\text { abroad 5+ years }\end{array}$ & $\begin{array}{c}\text { Migrant couples } \\
\text { abroad until 2007 }\end{array}$ \\
\hline \hline Power couple & $0.046^{* * *}$ & $0.065^{* * *}$ & $0.053^{* * *}$ & $0.055^{* * *}$ \\
Female power couple & $(0.000)$ & $(0.006)$ & $(0.012)$ & $(0.015)$ \\
& $0.044^{* * *}$ & $0.042^{* * *}$ & $0.050^{* * *}$ & $0.046^{* *}$ \\
Male power couple & $(0.000)$ & $(0.008)$ & $(0.016)$ & $(0.021)$ \\
Youngest child 0-6 & $-0.009^{* * *}$ & -0.006 & $-0.025^{* *}$ & -0.014 \\
& $(0.001)$ & $(0.006)$ & $(0.012)$ & $(0.015)$ \\
Youngest child 7+ & $-0.048^{* * *}$ & $-0.055^{* * *}$ & $-0.053^{* * *}$ & $-0.054^{* * *}$ \\
& $(0.000)$ & $(0.006)$ & $(0.012)$ & $(0.015)$ \\
Constant & $-0.019^{* * *}$ & -0.007 & -0.004 & -0.010 \\
& $(0.000)$ & $(0.008)$ & $(0.014)$ & $(0.018)$ \\
R-squared & $0.814^{* * *}$ & $0.751^{* * *}$ & $0.436^{* * *}$ & $0.910^{* * *}$ \\
Observations & $(0.002)$ & $(0.074)$ & $(0.161)$ & $(0.312)$ \\
\hline Solr & & & & 0.058 \\
& 0.028 & 0.049 & 0.064 & 2,937
\end{tabular}

Source: Register data.

Notes: OLS estimation. Standard errors in parentheses.

Female age and year dummies included.

*** Significant at the 1 percent level.

** Significant at the 5 percent level.

* Significant at the 10 percent level.

Table 12: Linear probability regressions: Female labor force participation in Denmark among non-migrant and migrant couples in $1982-2002$.

Table 13 analyzes the sorting of migrant couples into destination countries with respect to female labor force participation in Denmark. Again, we analyze separately migrant couples in which both partners stay abroad more than one year, more than five years and for those in which neither partner has returned until the end of 2007. The GINI coefficient for the migrants' future destination country indicates whether the dispersion of incomes in this country is small or large. The GINI

\footnotetext{
${ }^{19}$ The analysis again excludes couples in which either partner is retiree or student. In all specifications we control non-parametrically for calendar year and age of the female partner.
} 
refers to inequality in disposable incomes on the individual level taken from the UN World Income Inequality (WIID) database (2016) for the year 2008. We also include country group dummies (reference category: other Western countries) in alternative specifications. Including the GINI coefficient shows that female labor force participation in Denmark is lower among couples later migrating to countries with a larger dispersion of income and staying abroad at least until the end of 2007. These findings provide some evidence that couples sort into different destinations according to their family model in Denmark. The coefficient estimate for the GINI is statistically insignificant in the specification for emigrant couples staying at least one year as well as in the specification for those staying at least five years abroad. When controlling for destination country groups in the sample of migrant couples, results reveal that female labor force participation before emigration is statistically significantly lower among couples migrating to the US.

\begin{tabular}{|c|c|c|c|c|c|c|}
\hline \multirow[b]{2}{*}{ Power couple } & \multicolumn{2}{|c|}{$\begin{array}{l}\text { Migrant couples } \\
\text { abroad } 1+\text { years }\end{array}$} & \multicolumn{2}{|c|}{$\begin{array}{l}\text { Migrant couples } \\
\text { abroad } 5+\text { years }\end{array}$} & \multicolumn{2}{|c|}{$\begin{array}{l}\text { Migrant couples } \\
\text { abroad until } 2007\end{array}$} \\
\hline & $\begin{array}{c}0.060^{* * *} \\
(0.007)\end{array}$ & $\begin{array}{c}0.067^{* * *} \\
(0.006)\end{array}$ & $\begin{array}{c}0.051^{* * *} \\
(0.013)\end{array}$ & $\begin{array}{c}0.055^{* * *} \\
(0.012)\end{array}$ & $\begin{array}{c}0.054^{* * *} \\
(0.016)\end{array}$ & $\begin{array}{c}0.059 * * * \\
(0.015)\end{array}$ \\
\hline Female power couple & $\begin{array}{c}0.054^{* * *} \\
(0.010)\end{array}$ & $\begin{array}{c}0.044^{* * *} \\
(0.008)\end{array}$ & $\begin{array}{c}0.055^{* * *} \\
(0.018)\end{array}$ & $\begin{array}{c}0.051^{* * *} \\
(0.017)\end{array}$ & $\begin{array}{c}0.053^{* *} \\
(0.022)\end{array}$ & $\begin{array}{c}0.047^{* *} \\
(0.021)\end{array}$ \\
\hline Male power couple & $\begin{array}{l}-0.006 \\
(0.007)\end{array}$ & $\begin{array}{l}-0.006 \\
(0.006)\end{array}$ & $\begin{array}{c}-0.024^{*} \\
(0.013)\end{array}$ & $\begin{array}{l}-0.022^{*} \\
(0.012)\end{array}$ & $\begin{array}{l}-0.013 \\
(0.016)\end{array}$ & $\begin{array}{l}-0.008 \\
(0.016)\end{array}$ \\
\hline Youngest child 0-6 & $\begin{array}{c}-0.052^{* * *} \\
(0.007)\end{array}$ & $\begin{array}{c}-0.055^{* * *} \\
(0.006)\end{array}$ & $\begin{array}{c}-0.061^{* * *} \\
(0.012)\end{array}$ & $\begin{array}{c}-0.054^{* * *} \\
(0.012)\end{array}$ & $\begin{array}{c}-0.060^{* * *} \\
(0.016)\end{array}$ & $\begin{array}{c}-0.056^{* * *} \\
(0.015)\end{array}$ \\
\hline Youngest child $7+$ & $\begin{array}{l}-0.014 \\
(0.009)\end{array}$ & $\begin{array}{l}-0.007 \\
(0.008)\end{array}$ & $\begin{array}{l}-0.016 \\
(0.015)\end{array}$ & $\begin{array}{l}-0.004 \\
(0.014)\end{array}$ & $\begin{array}{l}-0.018 \\
(0.019)\end{array}$ & $\begin{array}{l}-0.010 \\
(0.018)\end{array}$ \\
\hline Gini & $\begin{array}{c}0.026 \\
(0.049)\end{array}$ & & $\begin{array}{l}-0.135 \\
(0.102)\end{array}$ & & $\begin{array}{c}-0.298^{* *} \\
(0.129)\end{array}$ & \\
\hline Nordic countries & & $\begin{array}{l}-0.010 \\
(0.007)\end{array}$ & & $\begin{array}{l}-0.016 \\
(0.012)\end{array}$ & & $\begin{array}{l}-0.004 \\
(0.014)\end{array}$ \\
\hline United States & & $\begin{array}{l}-0.010 \\
(0.008)\end{array}$ & & $\begin{array}{c}-0.061^{* * *} \\
(0.016)\end{array}$ & & $\begin{array}{c}-0.073^{* * *} \\
(0.019)\end{array}$ \\
\hline Non-Western countries & & $\begin{array}{c}-0.015^{* * *} \\
(0.006)\end{array}$ & & $\begin{array}{l}-0.024^{*} \\
(0.013)\end{array}$ & & $\begin{array}{l}-0.016 \\
(0.019)\end{array}$ \\
\hline Constant & $\begin{array}{c}0.736^{* * *} \\
(0.073)\end{array}$ & $\begin{array}{c}0.758^{* * *} \\
(0.074)\end{array}$ & $\begin{array}{c}0.473^{* * *} \\
(0.164)\end{array}$ & $\begin{array}{c}0.444^{* * *} \\
(0.161)\end{array}$ & $\begin{array}{c}0.990 * * * \\
(0.315)\end{array}$ & $\begin{array}{c}0.915^{* * *} \\
(0.311)\end{array}$ \\
\hline R-squared & 0.057 & 0.049 & 0.067 & 0.067 & 0.061 & 0.063 \\
\hline Observations & 12,423 & 15,982 & 4,492 & 5,090 & 2,669 & 2,937 \\
\hline
\end{tabular}

Source: Register data.

Notes: OLS estimation. Standard errors in parentheses.

Female age and year dummies included.

*** Significant at the 1 percent level.

** Significant at the 5 percent level.

* Significant at the 10 percent level.

Table 13: Linear probability regressions: Female labor force participation in Denmark among migrant couples in $1982-2002$. 


\subsection{Female Labor Force Participation Abroad}

Female labor force participation among emigrant couples is considerably lower in 2008 compared to before emigration. With our survey data we are able to analyze the determinants of lower female labor force participation abroad in more detail and explicitly test the hypotheses derived from the theoretical model against alternative explanatory channels. We estimate a linear probability regression on the sample of survey respondents and their partners to analyze the determinants for female labor force participation abroad. ${ }^{20}$ In Table 14, we include as baseline explanatory variables the couple's power type (reference category: low power couples) and indicator variables for children in the household. We also include the GINI coefficient for the country of residence in 2008 as a regressor. In an alternative specification, we include country group dummies (reference category: other Western countries) which additionally control for between-country variation in language, culture and other factors which might be related to female labor force participation in those countries. In all specifications female age dummies are included as control variables. ${ }^{21}$

Estimates in Table 14 show that female labor force participation is particularly low in male power couples confirming Hypothesis 1 derived from our model. In Table B9 we additionally include a variable for the female being tied mover which indicates whether the survey respondent stated that the job of the male partner was the main motivation to emigrate. Among couples having migrated mainly for male job opportunities, female labor force participation is particularly low. This confirms Hypothesis 2 from our model. Furthermore, estimation results in Table 14 reveal that the presence of children is negatively associated with female labor force participation. This is especially the case if the youngest child is below the age of 7 which is in line with Hypothesis 3 from our model. The second column indicates that female labor force participation is lower in countries with wider income differences, which confirms Hypothesis 4. Comparing the R-squared measure between columns 1 and 2 indicates that differences in income inequality between destination countries explain a considerable part of the variation in female labor force participation. Estimates for the country group dummies in column 3 suggest that female labor force participation in the Nordic countries is more likely than in the non-Nordic countries. ${ }^{22}$ In column 4 we interact the Nordic country dummy with dummy variables for the youngest children below age seven and for the youngest child aged seven or older. Results reveal that higher female labor force participation among couples in the Nordic countries is driven by higher female labor force partici-

\footnotetext{
${ }^{20}$ We exclude couples in which either partner is retiree or student in 2008.

${ }^{21} \mathrm{We}$ are not able to match register data information on age for all partners of the respondents. This is the reason for a reduced number of observations compared to the analysis in section 4 .

${ }^{22}$ We do not include the GINI coefficient in these regressions as most of the variation in the GINI is between the country groups rather than within them.
} 
pation among the group in which the youngest child is below the age of seven. On the other hand, there are strong negative effects of having young children on female labor force participation in the non-Nordic countries. In Table B10 we also present results including the "Starting Well Index", an index capturing the availability, affordability and quality of child care services in a subset of countries (The Economist Intelligence Unit, 2012). Results reveal that a higher value of this index is associated with higher female labor force participation which is also in line with our theory. The effect of the GINI coefficient is robust to including the "Starting Well Index". In case a couple has children the public provision of child care services provides incentives for labor market participation of both partners. Our model predicts that a lower price of child care would incentivize higher female labor force participation. Moreover, couples emigrating to a country where the provision of child care is low might be those preferring to spend more time with their children.

In Table B11 we additionally include an indicator of the work status of the female in Denmark before migration. If the female worked before migration, we estimate a significantly higher probability for actual labor force participation abroad. The size and significance of most coefficient estimates still remain unchanged.

Table 15 shows that actual labor force participation generally reflects the preferred division of labor among the partners. In a similar framework to Table 14, we relate the explanatory variables to an indicator of whether the respondent prefers that either both partners work or only the female partner works. In almost all cases this means a preference for both partners working. Most coefficient estimates are similar in sign and size to the specifications in Table 14. The presence of young children is negatively correlated with positive attitudes towards female labor force participation. Again, we observe for the non-Nordic countries that the presence of children is negatively related to positive attitudes towards the female partner participating in the labor market. On the other hand, among couples with the youngest child below the age of seven in the Nordic countries, preferences for female labor force participation are statistically significantly higher than in the non-Nordic countries.

Coefficient estimates for the GINI variable indicate that larger income differences in the country of residence are associated with lower preferences towards the female partner being in the labor market, as reflected in actual labor force participation outcomes. Estimation results for the explanatory factors described above are in line with predictions from our theoretical model. Differences in child care prices and in wage distribution can rationalize differences in preferences for female labor force 


\begin{tabular}{|c|c|c|c|c|}
\hline Power couple & $\begin{array}{l}-0.011 \\
(0.059)\end{array}$ & $\begin{array}{c}-0.031 \\
(0.059)\end{array}$ & $\begin{array}{c}0.007 \\
(0.057)\end{array}$ & $\begin{array}{c}0.018 \\
(0.058)\end{array}$ \\
\hline Female power couple & $\begin{array}{c}0.026 \\
(0.082)\end{array}$ & $\begin{array}{l}-0.005 \\
(0.082)\end{array}$ & $\begin{array}{c}-0.004 \\
(0.079)\end{array}$ & $\begin{array}{c}0.010 \\
(0.079)\end{array}$ \\
\hline Male power couple & $\begin{array}{c}-0.233^{* * *} \\
(0.070)\end{array}$ & $\begin{array}{c}-0.202^{* * *} \\
(0.071)\end{array}$ & $\begin{array}{c}-0.170^{* *} \\
(0.067)\end{array}$ & $\begin{array}{c}-0.162^{* *} \\
(0.067)\end{array}$ \\
\hline Youngest child $0-6$ & $\begin{array}{c}-0.229^{* * *} \\
(0.069)\end{array}$ & $\begin{array}{c}-0.191^{* * *} \\
(0.067)\end{array}$ & $\begin{array}{c}-0.186^{* * *} \\
(0.066)\end{array}$ & $\begin{array}{c}-0.254^{* * *} \\
(0.075)\end{array}$ \\
\hline Youngest child $7+$ & $\begin{array}{c}-0.151^{* *} \\
(0.060)\end{array}$ & $\begin{array}{c}-0.133^{* *} \\
(0.059)\end{array}$ & $\begin{array}{c}-0.139 * * \\
(0.057)\end{array}$ & $\begin{array}{c}-0.178^{* * *} \\
(0.064)\end{array}$ \\
\hline Gini & & $\begin{array}{c}-2.296^{* * *} \\
(0.400)\end{array}$ & & \\
\hline Nordic countries & & & $\begin{array}{c}0.215^{* * *} \\
(0.053)\end{array}$ & $\begin{array}{c}0.070 \\
(0.103)\end{array}$ \\
\hline United States & & & $\begin{array}{c}-0.206^{* * *} \\
(0.056)\end{array}$ & $\begin{array}{c}-0.201^{* * *} \\
(0.055)\end{array}$ \\
\hline Non-Western countries & & & $\begin{array}{c}-0.143^{* *} \\
(0.063)\end{array}$ & $\begin{array}{c}-0.138^{* *} \\
(0.063)\end{array}$ \\
\hline Youngest child $0-6 *$ Nordic & & & & $\begin{array}{c}0.246^{*} \\
(0.130)\end{array}$ \\
\hline Youngest child $7+{ }^{*}$ Nordic & & & & $\begin{array}{c}0.140 \\
(0.129)\end{array}$ \\
\hline Constant & $\begin{array}{c}0.747^{* * *} \\
(0.115)\end{array}$ & $\begin{array}{c}1.448^{* * *} \\
(0.165)\end{array}$ & $\begin{array}{c}0.669^{* * *} \\
(0.113)\end{array}$ & $\begin{array}{c}0.727^{* * *} \\
(0.119)\end{array}$ \\
\hline R-squared & 0.180 & 0.242 & 0.262 & 0.268 \\
\hline Observations & 474 & 437 & 474 & 474 \\
\hline
\end{tabular}

Sources: Survey and register data.

Notes: OLS estimation. Standard errors in parentheses.

Female age dummies included.

*** Significant at the 1 percent level.

** Significant at the 5 percent level.

* Significant at the 10 percent level.

Table 14: Linear probability regressions: Female labor force participation abroad in 2008. 


\begin{tabular}{|c|c|c|c|c|}
\hline Power couple & $\begin{array}{c}0.074 \\
(0.064)\end{array}$ & $\begin{array}{c}0.059 \\
(0.064)\end{array}$ & $\begin{array}{c}0.100 \\
(0.062)\end{array}$ & $\begin{array}{l}0.112^{*} \\
(0.063)\end{array}$ \\
\hline Female power couple & $\begin{array}{l}-0.035 \\
(0.090)\end{array}$ & $\begin{array}{l}-0.064 \\
(0.091)\end{array}$ & $\begin{array}{l}-0.045 \\
(0.087)\end{array}$ & $\begin{array}{c}-0.031 \\
(0.088)\end{array}$ \\
\hline Male power couple & $\begin{array}{c}-0.165^{* *} \\
(0.077)\end{array}$ & $\begin{array}{c}-0.174^{* *} \\
(0.078)\end{array}$ & $\begin{array}{c}-0.112 \\
(0.075)\end{array}$ & $\begin{array}{c}-0.103 \\
(0.075)\end{array}$ \\
\hline Youngest child $0-6$ & $\begin{array}{c}-0.262^{* * *} \\
(0.074)\end{array}$ & $\begin{array}{c}-0.230^{* * * *} \\
(0.073)\end{array}$ & $\begin{array}{c}-0.227^{* * *} \\
(0.072)\end{array}$ & $\begin{array}{c}-0.298^{* * *} \\
(0.083)\end{array}$ \\
\hline Youngest child $7+$ & $\begin{array}{c}-0.234^{* * * *} \\
(0.065)\end{array}$ & $\begin{array}{c}-0.205^{* * * *} \\
(0.065)\end{array}$ & $\begin{array}{c}-0.217^{* * *} \\
(0.063)\end{array}$ & $\begin{array}{c}-0.257 * * * \\
(0.071)\end{array}$ \\
\hline Gini & & $\begin{array}{c}-1.981^{* * *} \\
(0.428)\end{array}$ & & \\
\hline Nordic countries & & & $\begin{array}{c}0.178^{* * *} \\
(0.058)\end{array}$ & $\begin{array}{c}0.039 \\
(0.112)\end{array}$ \\
\hline United States & & & $\begin{array}{c}-0.218^{* * *} \\
(0.060)\end{array}$ & $\begin{array}{c}-0.215^{* * *} \\
(0.060)\end{array}$ \\
\hline Non-Western countries & & & $\begin{array}{c}0.015 \\
(0.070)\end{array}$ & $\begin{array}{c}0.018 \\
(0.070)\end{array}$ \\
\hline Youngest child $0-6 *$ Nordic & & & & $\begin{array}{c}0.248^{*} \\
(0.141)\end{array}$ \\
\hline Youngest child $7+{ }^{*}$ Nordic & & & & $\begin{array}{c}0.123 \\
(0.014)\end{array}$ \\
\hline Constant & $\begin{array}{c}1.003^{* * *} \\
(0.121)\end{array}$ & $\begin{array}{c}1.613^{* * *} \\
(0.177)\end{array}$ & $\begin{array}{c}0.934^{* * *} \\
(0.120)\end{array}$ & $\begin{array}{c}0.991 \\
(0.127)\end{array}$ \\
\hline R-squared & 0.154 & 0.219 & 0.216 & 0.222 \\
\hline Observations & 440 & 408 & 440 & 440 \\
\hline
\end{tabular}

Sources: Survey and register data.

Notes: OLS estimation. Standard errors in parentheses.

Female age dummies included.

*** Significant at the 1 percent level.

** Significant at the 5 percent level.

* Significant at the 10 percent level.

Table 15: Linear probability regressions: Preference for female labor force participation. 
participation between the countries of residence. Child care programs in the Nordic countries are far more generous compared to other countries. This could explain why having young children does not seem to be a strong impediment to female labor force participation among couples living in other Nordic countries and why preference towards female labor force participation among the emigrant couples is higher in those countries. The provision of subsidies in the Nordic countries lowers the price for child care services and increases incentives for female labor force participation.

The coefficient estimates for the Nordic country and the US dummy in Table 15 are similar in sign and size as in Table 14. We interpret this as evidence that the differences in labor force participation reflect actual preferences and are to a lesser extent driven by legal work restrictions for family migrants. The coefficient estimate for the non-Western country dummy indicates that actual labor force participation of the female partner is lower than preferred labor force participation. This suggests that other restrictions or the lack of employment opportunities for the female partner might play a role in explaining low female labor force participation among couples in these countries. We can show that our results as in Tables 14 and 15 are robust to weighting respondents with the inverse probability for being in the sample given the target population of survey. We explain the weighting procedure and present the corresponding results in Appendix C.

Fernández et al. (2004) find evidence for the US that wives of men whose mothers worked are themselves significantly more likely to work. Along the same lines, Moen et al. (1997) provide evidence that daughters' and mothers' gender role identities are closely related, including preferences towards the division of labor in the household. For Table 16, we take the second and the third specification from Table 14 and Table 15 and add an additional regressor capturing labor force participation of the mother of the respondent at the age of 12 . The idea is, first, to test whether preferences towards the division of labor are transmitted to the children. Columns 1 and 2 indicate that the respondent is slightly more likely to prefer a male breadwinner model if the parents' household economy was more traditional - after including the same covariates as in Table 15. Robustness analysis confirms that these results do not depend on whether the respondent was male or female. However, when explaining actual female labor force participation abroad, the coefficient estimate for labor force participation of the respondent's mother becomes insignificant.

A potential alternative explanation for our findings is that labor force participation among females in our sample converges systematically to the average female labor force participation rates in the destination countries. MacPherson and Steward (1989) provide evidence on assimilation of female 


\begin{tabular}{|c|c|c|c|c|}
\hline \multirow[b]{2}{*}{ Power couple } & \multicolumn{2}{|c|}{$\begin{array}{c}\text { Preference for } \\
\text { female labor force } \\
\text { participation }\end{array}$} & \multicolumn{2}{|c|}{$\begin{array}{c}\text { Actual } \\
\text { female labor force } \\
\text { participation }\end{array}$} \\
\hline & $\begin{array}{c}0.056 \\
(0.064)\end{array}$ & $\begin{array}{c}0.099 \\
(0.062)\end{array}$ & $\begin{array}{l}-0.035 \\
(0.059)\end{array}$ & $\begin{array}{c}0.006 \\
(0.057)\end{array}$ \\
\hline Female power couple & $\begin{array}{l}-0.059 \\
(0.091)\end{array}$ & $\begin{array}{l}-0.039 \\
(0.087)\end{array}$ & $\begin{array}{l}-0.003 \\
(0.082)\end{array}$ & $\begin{array}{l}-0.003 \\
(0.079)\end{array}$ \\
\hline Male power couple & $\begin{array}{c}-0.170^{* *} \\
(0.078)\end{array}$ & $\begin{array}{c}-0.107 \\
(0.075)\end{array}$ & $\begin{array}{c}-0.201^{* * *} \\
(0.071)\end{array}$ & $\begin{array}{c}-0.170^{* *} \\
(0.067)\end{array}$ \\
\hline Youngest child 0-6 & $\begin{array}{c}-0.238^{* * *} \\
(0.073)\end{array}$ & $\begin{array}{c}-0.235^{* * *} \\
(0.072)\end{array}$ & $\begin{array}{c}-0.195^{* * *} \\
(0.067)\end{array}$ & $\begin{array}{c}-0.187^{* * *} \\
(0.066)\end{array}$ \\
\hline Youngest child $7+$ & $\begin{array}{c}-0.189^{* * *} \\
(0.065)\end{array}$ & $\begin{array}{c}-0.205^{* * * *} \\
(0.063)\end{array}$ & $\begin{array}{c}-0.120^{* *} \\
(0.059)\end{array}$ & $\begin{array}{c}-0.135^{* *} \\
(0.058)\end{array}$ \\
\hline Gini & $\begin{array}{c}-2.035^{* * *} \\
(0.428)\end{array}$ & & $\begin{array}{c}-2.353^{* * *} \\
(0.400)\end{array}$ & \\
\hline Nordic countries & & $\begin{array}{c}0.170^{* * *} \\
(0.058)\end{array}$ & & $\begin{array}{c}0.214^{* * *} \\
(0.053)\end{array}$ \\
\hline United States & & $\begin{array}{c}-0.225^{* * *} \\
(0.060)\end{array}$ & & $\begin{array}{c}-0.208^{* * *} \\
(0.056)\end{array}$ \\
\hline Non-Western countries & & $\begin{array}{c}0.017 \\
(0.070)\end{array}$ & & $\begin{array}{c}-0.143^{* *} \\
(0.063)\end{array}$ \\
\hline $\begin{array}{l}\text { Mother out of labor force } \\
\text { at respondent's age } 12\end{array}$ & $\begin{array}{c}-0.097^{*} \\
(0.052)\end{array}$ & $\begin{array}{c}-0.091^{*} \\
(0.050)\end{array}$ & $\begin{array}{l}-0.078 \\
(0.048)\end{array}$ & $\begin{array}{l}-0.024 \\
(0.046)\end{array}$ \\
\hline Constant & $\begin{array}{c}1.670^{* * *} \\
(0.179)\end{array}$ & $\begin{array}{c}0.973^{* * *} \\
(0.122)\end{array}$ & $\begin{array}{c}1.498^{* * *} \\
(0.168)\end{array}$ & $\begin{array}{c}0.679 * * * \\
(0.114)\end{array}$ \\
\hline R-squared & 0.226 & 0.222 & 0.247 & 0.263 \\
\hline Observations & 408 & 440 & 437 & 474 \\
\hline
\end{tabular}

Sources: Survey and register data.

Notes: OLS estimation. Standard errors in parentheses.

Female age dummies included.

*** Significant at the 1 percent level.

** Significant at the 5 percent level.

* Significant at the 10 percent level.

Table 16: Linear probability regressions: Intergenerational transmission and female labor force participation. 


\begin{tabular}{|c|c|c|c|c|}
\hline \multirow[b]{2}{*}{ Power couple } & \multicolumn{2}{|c|}{ All countries } & \multicolumn{2}{|c|}{$\begin{array}{c}\text { Non-Nordic } \\
\text { countries }\end{array}$} \\
\hline & $\begin{array}{l}-0.013 \\
(0.059)\end{array}$ & $\begin{array}{l}-0.031 \\
(0.059)\end{array}$ & $\begin{array}{c}0.021 \\
(0.072)\end{array}$ & $\begin{array}{l}-0.002 \\
(0.076)\end{array}$ \\
\hline Female power couple & $\begin{array}{c}0.026 \\
(0.083)\end{array}$ & $\begin{array}{c}-0.0055 \\
(0.082)\end{array}$ & $\begin{array}{c}0.012 \\
(0.107)\end{array}$ & $\begin{array}{c}0.020 \\
(0.113)\end{array}$ \\
\hline Male power couple & $\begin{array}{c}-0.228^{* * *} \\
(0.070)\end{array}$ & $\begin{array}{c}-0.201^{* * *} \\
(0.071)\end{array}$ & $\begin{array}{c}-0.143^{*} \\
(0.082)\end{array}$ & $\begin{array}{c}-0.146^{*} \\
(0.086)\end{array}$ \\
\hline Youngest child 0-6 & $\begin{array}{c}-0.229^{* * *} \\
(0.069)\end{array}$ & $\begin{array}{c}-0.190^{* * *} \\
(0.068)\end{array}$ & $\begin{array}{c}-0.242^{* * *} \\
(0.086)\end{array}$ & $\begin{array}{c}-0.217^{* *} \\
(0.089)\end{array}$ \\
\hline Youngest child $7+$ & $\begin{array}{c}-0.151^{* *} \\
(0.060)\end{array}$ & $\begin{array}{c}-0.134^{* *} \\
(0.059)\end{array}$ & $\begin{array}{c}-0.206^{* * *} \\
(0.072)\end{array}$ & $\begin{array}{c}-0.200^{* * * *} \\
(0.074)\end{array}$ \\
\hline Gini & & $\begin{array}{c}-2.306^{* * *} \\
(0.401)\end{array}$ & & $\begin{array}{c}-1.472^{* *} \\
(0.624)\end{array}$ \\
\hline FLFP rate at destination & $\begin{array}{c}0.021 \\
(0.352)\end{array}$ & $\begin{array}{c}0.182 \\
(0.401)\end{array}$ & $\begin{array}{c}-0.688^{*} \\
(0.402)\end{array}$ & $\begin{array}{l}-0.375 \\
(0.535)\end{array}$ \\
\hline Constant & $\begin{array}{c}0.735^{* * *} \\
(0.235)\end{array}$ & $\begin{array}{c}1.347^{* * *} \\
(0.278)\end{array}$ & $\begin{array}{c}0.925^{* * *} \\
(0.273)\end{array}$ & $\begin{array}{c}1.248^{* * *} \\
(0.318)\end{array}$ \\
\hline R-squared & 0.179 & 0.242 & 0.216 & 0.236 \\
\hline Observations & 473 & 437 & 372 & 336 \\
\hline
\end{tabular}

Sources: Survey data, register data, and ILO.

Notes: OLS estimation. Robust standard errors in parentheses.

Female labor force participation (FLFP) rate according to estimates

by International Labour Organization for 2008.

*** Significant at the 1 percent level.

** Significant at the 5 percent level.

* Significant at the 10 percent level.

Table 17: Linear probability regressions: Actual female labor force participation of emigrants and female labor force participation rates in the country of residence. 
labor force participation rates among immigrants in the US. Female labor force participation rates among the native population are generally higher in the Nordic countries while they are lower in other Western countries and the US (OECD, 2015). However, the differences of these rates between the considered country groups are considerably smaller compared to differences we observe among the emigrant couples in our sample. Other research (e.g. Antecol (2000), Fernández and Fogli (2009) and Blau et al. (2011)) has argued that cultural background has a lasting impact on migrant families' labor supply decisions. Female labor force participation tends to be higher among families coming from countries with historically stronger female labor force attachment. Couples in our sample have the same cultural background but are exposed to different prices and institutional environments in the countries of residence.

In Table 17 we include female labor force participation rates in the country of residence to explain female labor force participation in our sample abroad. Column 1 shows that the probability for the female partner participating in the labor force seems to be higher when the female labor force participation rate in the country of residence population is high. However, this relationship is statistically insignificant and breaks down when excluding the Nordic countries from the sample: then a higher female labor force participation rate in the country of residence is not anymore associated with an increase in female labor force participation among the couples. Including the GINI coefficient in the regressions in Table 17 increases the R-squared substantially suggesting that the partners' relative wages play an important role for female labor force participation as suggested by our model. The alternative hypothesis that female labor force participation converges to the prevailing rate in the country of residence fails to explain our findings.

Table B12 provides sensitivity analysis for the results with respect to the emigration years in our data. We do not find differences between the results for couples having emigrated in the earlier years 1987/88, 1992/93, 1997/98 compared with the later cohorts having emigrated in 2001/02. This additionally confirms that our results do not seem to be driven by an assimilation process towards average labor force participation rates in the destination countries.

\section{Conclusion}

Using administrative data we analyzed self-selection of Danish couples into emigration and sorting across different destinations with respect to the partners' pre-migration labor force participation. 
Survey data on couples having emigrated permanently allowed us to gain insights into the partners' motivations to emigrate and their labor force participation abroad. Despite Denmark being one of the most gender-equal countries worldwide, we found big gender differences in main motivations to emigrate and in female labor force participation abroad. Own work was the main reason to emigrate for $74.7 \%$ of men and $21.7 \%$ of women, partner's job or other family reasons for $6.0 \%$ of men and $53.0 \%$ of women. Accordingly, Danish emigrant couples often adopt more traditional gender roles in non-Nordic countries with a male breadwinner and the female staying at home. In the US, the male works in almost all couples and the female in half of the couples. In the other Western countries, both partners work in two thirds of couples, and the male works while the female stays at home in one quarter of couples. The male stays at home and the female works in less than one percent of couples that have emigrated and live in destinations outside other Nordic countries.

Lower female labor force participation could reflect both demand and supply side effects. Potential legal constraints or a lack of labor market opportunities could force the female partner out of the labor force, but it could also be that lower female labor supply is an adjustment to wider wage differences abroad. Furthermore there could be Tiebout sorting so that couples preferring a more traditional male breadwinner model would be more likely to migrate outside the Nordic countries. Our results suggest that both demand and supply side mechanisms are important. Demand side restrictions appear to play a role especially in non-Western countries, where the share of couples in which only the male works is considerably larger than the share of couples stating that they prefer such a situation. In the Western countries, preferred and actual female labor force participation are closely in line, suggesting the primacy of labor supply decisions. Our theoretical framework illustrates the role of incentives in this context: wider income differences as well as higher prices for child care can economically rationalize that the female partner reduces labor supply or stays out of the labor force. The empirical findings for female labor force participation abroad confirmed the hypotheses derived from our model. After migration female labor force participation is lower in countries with wider income differences, such as the US. Reduced female labor force participation in the US and non-Western countries is particularly evident among couples with pre-school age children.

We also found evidence that couples self-selected into emigration according to their division of labor in Denmark: despite the prevalence of the dual-earner model among couples before emigration in Denmark, couples were more likely to emigrate in case one partner, in most cases the 
female, had been out of the labor force. We found some evidence for sorting into destinations according to pre-migration labor force participation patterns. Couples having emigrated to the US had slightly more often adopted a male breadwinner model already before migration. These pre-migration differences are rather small compared with the decline in female labor force participation among the migrant couples outside the Nordic countries. Moreover, a significant fraction of couples with children migrating outside the Nordic countries viewed considerations related to children as a reason to emigrate, and very few as a reason against emigration. Among couples migrating to other Nordic countries, very few viewed considerations related to children being either in favor or against emigration. One possible explanation for this is that those parents who prefer that one of them, most likely the mother, takes care of their children at home, would be more likely to emigrate outside the Nordic countries. There they switch from the dual-earner model to the male breadwinner model. This explanation is in line with the observation that the presence of young children significantly reduces female labor force participation outside the Nordic countries, while its effect is small and statistically insignificant in the other Nordic countries. In the light of increasingly international competition for talent, this might reduce incentives for females to invest in their careers if they expect to accompany their partner as tied movers later in life. 


\section{References}

Akerlof, G. A. and R. E. Kranton, Economics and identity. The Quarterly Journal of Economics, 115(3): 715-753, 2000.

Angelov, N., P. Johansson, and E. Lindahl, Parenthood and the gender gap in pay. Journal of Labor Economics, 34(3): 545-579, 2016.

Antecol, H.: An examination of cross-country differences in the gender gap in labor force participation rates. Labour Economics, 7(4): 409-426, 2000.

Apps, P. F. and R. Rees, Taxation and the household. Journal of Public Economics, 35(3): 355-369, 1988.

Baker, M., J. Gruber and K. Milligan, Universal child care, maternal labor supply, and family well-being. Journal of Political Economy, 116(4): 709-745, 2008.

Becker, G. S., A theory of marriage: Part ii. Journal of Political Economy, 82(2): S11-S26, 1974.

Becker, G. S., A Treatise on the family. Enlarged edn. Harvard University Press, Cambridge, 1991.

Bertrand, M., New perspectives on gender, In Handbook of Labor Economics. O. Ashenfelter and D. Card eds., 1545-1592, 2011.

Bertrand, M., E. Kamenica and J. Panet, Gender identity and relative income within households. Quarterly Journal of Economics, 130(2): 571-614, 2015.

Blau, F. D., L. M. Kahn and K. L. Papps, Gender, source country characteristics, and labor market assimilation among immigrants. The Review of Economics and Statistics, 93(1): 43-58, 2011.

Borjas, G. J., Self-Selection and the earnings of immigrants. American Economic Review, 77(4): 531-553, 1987.

Borjas, G. J. and B. Bratsberg, Who leaves? The outmigration of the foreign-born. Review of Economics and Statistics, 78(1): 165-176, 1996.

Borjas, G. J. and S.G. Bronars, Immigration and the family. Journal of Labor Economics, 9(2): 123-148, 1991. 
Borjas, G. J., I. Kauppinen and P. Poutvaara, Self-selection of emigrants: Theory and evidence on stochastic dominance in observable and unobservable characteristics. CESifo WP NO. $5567,2015$.

Browning, M., P.-A. Chiappori and Y. Weiss, Economics of the family. Cambridge: Cambridge Univ. Press, 2014.

Cherchye, L., B. De Rock and F. Vermeulen, Married with children: A collective labor supply model with detailed time use and intrahousehold expenditure information. American Economic Review, 102(7): 3377-3405, 2012.

Chiappori, P.-A., Rational household labor supply. Econometrica, 56(1): 63-90, 1988.

Chiappori, P.-A., Collective labor supply and welfare. Journal of Political Economy, 100(3): 437-67, 1992 .

Cochran, W., The effectiveness of adjustment by subclassification in removing bias in observational studies. Biometrics, 24: 295-313, 1968.

Costa, D. L. and M. E. Kahn, Power couples: Changes in the locational choice of the college educated, 1940-1990. The Quarterly Journal of Economics, 115(4): 1287-1315, 2000.

Del Boca, D., C. Flinn and M. Wiswall, Household choices and child development. Review of Economic Studies, 81(1): 137-185, 2014.

Docquier, F., and H. Rapoport, The Economics of migrants' remittances. Handbook on the Economics of Giving, Reciprocity and Altruism, 2006.

Dustmann, C. and J.-S. Görlach, The economics of temporary migrations. Journal of Economic Literature, 54(1): 98-136, 2016.

Fernández, R. and A. Fogli, Culture: An empirical investigation of beliefs, work, and fertility. American Economic Journal: Macroeconomics, 1(1): 146-177, 2009.

Fernández, R., A. Fogli and C. Olivetti, Mothers and sons: Preference formation and female labor force dynamics. The Quarterly Journal of Economics, 119(4): 1249-1299, 2004.

Foerster, M and P. Whiteford, How much redistribution do welfare states achieve? The role of cash transfers and household taxes. CESifo DICE Report, 3/2009: 34-41, 2009.

Foged, M., Family migration and relative earnings potentials. Labour Economics 42: 87-100, 2016 . 
Goldin, C., The quiet revolution that transformed women's employment, education, and family. American Economic Review, 96(2): 1-21, 2006.

Grogger J. and G. Hanson, Income maximization and the selection and sorting of international migrants. Journal of Development Economics, 95(1): 42-57, 2010.

Havnes, T. and M. Mogstad, Is universal childcare leveling the playing field? Journal of Public Economics, 127: 100-144, 2015.

Herbst, C. M., Universal child care, maternal employment, and children's long-run outcomes: evidence from the U.S. Lanham Act of 1940. Journal of Labor Economics, forthcoming.

John, D and B. A. Shelton, The division of household labor. Annual Review of Sociology, 22: 299-322, 1996.

Junge, M., M.D. Munk and P. Poutvaara, International migration of couples. IZA Discussion Paper No. 8352, 2014.

Kiernan, K., Unmarried cohabitation and parenthood in Britain and Europe. Law and Policy 26(1): 33-55, 2004.

Klugman, J., Human Development Report 2011. Sustainability and equity: A better future for all. UNDP-HDRO Human Development Reports, 2011.

Kottelenberg, M. J. and S. F. Lehrer, Do the perils of universal childcare depend on the child's age? CESifo Economic Studies, 60(2): 338-365, 2014.

Lewis, T., Weighting adjustment methods for nonresponse in surveys, WUSS proceedings 162, 2012.

MacPherson, D. and J.B. Stewart, The labor force participation and earnings profiles of married female immigrants. Quarterly Review of Economics and Business, 29(3): 57-72, 1989.

Mincer, J., Family migration decisions. Journal of Political Economy, 86: 749-773, 1978.

Moen, P., M. A. Erickson and D. Dempster-McClain, Their mother's daughters? The intergenerational transmission of gender attitudes in a world of changing roles. Journal of Marriage and Family, 59(2): 281-293, 1997.

Mont, D., Two earner family migration. Journal of Population Economics, 2(1): 55-72, 1989.

OECD, OECD Employment Outlook 2015. 
Statistics Denmark, Denmark in Figures 2009.

The Economist Intelligence Unit, Starting well: Benchmarking early education across the world. 2012

Tiebout, C.M., A pure theory of local expenditures. Journal of Political Economy, 64(5): 416-424, 1956.

United Nations, Department of Economic and Social Affairs, Trends in international migrant stock: Migrants by destination and origin. United Nations database, POP/DB/ MIG/Stock/Rev.2013, 2015.

United Nations, WIID - World Income Inequality Database. www.wider.unu.edu/project/wiid, 2016. 


\section{Appendix A}

\section{Household utility maximization in the model}

We present the solutions of our model separately for five cases. Under (i) and (ii), we consider the case where $w_{a} \geq w_{b}$ and partners specialize according to comparative advantage, i.e. $a$ on labor market and $b$ on household work. We also assume this specialization pattern if $w_{a}=w_{b}$. Under (i) child care is provided privately in the household $\left(w_{b}<p_{D}\right.$ and $\left.D=0\right)$, under (ii) child care is bought on the market $\left(w_{b} \geq p_{D}\right.$ and $\left.D=\bar{D}\right)$. For both (i) and (ii), we present three different household labor supply regimes: First, a might specialize fully on working in the labor market while $b$ divides time between labor market and household production. Second there might be full specialization with $a$ working full-time in the labor market and $b$ in household production. Third, $b$ might specialize fully on household production and $a$ divides time between labor market and household production. The solutions for (iii), when $w_{b}>w_{a}$ and $\lambda=0$ or sufficiently small, follow by switching indices in (i) and (ii). In (iv) and (v), we present the solutions for $w_{b}>w_{a}$, when $\lambda>>0$. Under (iv) child care is provided privately $\left(w_{b}<p_{D}\right.$ and $\left.D=0\right)$, under $(\mathrm{v})$ it is bought on the market $\left(w_{b} \geq p_{D}\right.$ and $\left.D=\bar{D}\right)$. For both (iv) and $(\mathrm{v})$, there are two different household labor supply regimes: First, $a$ might specialize fully on working in the labor market while $b$ divides time between labor market and household production. Second, $b$ might specialize fully on household production and $a$ divides time between labor market and household production. We will show that under (iv) and (v) there is no regime where one partner fully specializes in working in the labor market while the other partner works full-time in the household. First, we analyze the interior solutions for labor supply of partner $b$ while $a$ works full-time in the labor market. For (i), (ii), (iv) and (v), the first-order conditions to the utility maximization problem are as follows.

$$
\begin{aligned}
\left.\frac{\partial U}{\partial H_{b}}\right|_{H_{a}=0} & =0 \\
\Rightarrow H_{b}^{*} & =(1-\alpha)\left(\frac{w_{a}}{w_{b}}+1\right)+\alpha \bar{D}, \text { if } w_{b}<p_{D} \text { and } D=0 \\
\left.\frac{\partial U}{\partial H_{b}}\right|_{H_{a}=0} & =0 \\
\Rightarrow H_{b}^{*} & =(1-\alpha)\left(\frac{w_{a}}{w_{b}}+1-\frac{p_{D}}{w_{b}} \bar{D}\right), \text { if } w_{b} \geq p_{D} \text { and } D=\bar{D}
\end{aligned}
$$

The corresponding first-order conditions for an interior solution for labor supply of partner $a$ while $b$ works full-time in the household are 


$$
\begin{aligned}
\left.\frac{\partial U}{\partial H_{a}}\right|_{H_{b}=1} & =0 \\
\Rightarrow H_{a}^{*} & =1-2 \alpha+\alpha \bar{D}, \text { if } w_{b}<p_{D} \text { and } D=0 \\
\left.\frac{\partial U}{\partial H_{a}}\right|_{H_{b}=1} & =0 \\
\Rightarrow H_{a}^{*} & =1-2 \alpha-(1-\alpha) \frac{p_{D}}{w_{a}} \bar{D}, \text { if } w_{b} \geq p_{D} \text { and } D=\bar{D} .
\end{aligned}
$$

The second-order conditions for global maxima are satisfied. Solutions for (iii) can be obtained by switching indices $a$ and $b$. Next, we check for each case whether $0 \leq H_{a}^{*} \leq 1$ and $0 \leq H_{b}^{*} \leq 1$ for the given parameter values $0 \leq \alpha \leq 1,0 \leq \bar{D} \leq 1, w_{a}>0, w_{b}>0$ and $p_{D}>0$.

(i) If $w_{a} \geq w_{b}$ and $w_{b}<p_{D}$,

$$
\begin{array}{lll}
H_{a}^{*} \geq 0, H_{b}^{*}=1 & \text { if } & \alpha \leq \frac{1}{2-\bar{D}} \\
H_{a}^{*}=0, H_{b}^{*} \leq 1 & \text { if } & \frac{w_{a}}{w_{a}+w_{b}-w_{b} \bar{D}} \leq \alpha .
\end{array}
$$

If $w_{a}=w_{b}$, then $\frac{1}{2-\bar{D}}=\frac{w_{a}}{w_{a}+w_{b}-w_{b} \bar{D}}$. If $w_{a}>w_{b}$, then $\frac{1}{2-\bar{D}}<\frac{w_{a}}{w_{a}+w_{b}-w_{b} \bar{D}}$ and there are parameter values for $\alpha$ without an interior solution.

In the following, we show that full specialization, $H_{a}=0, H_{b}=1$, is only optimal if $\frac{1}{2-\bar{D}} \leq \alpha \leq$ $\frac{w_{a}}{w_{a}+w_{b}-w_{b} \bar{D}}$. We show formally that full specialization of the partners never yields highest utility if a feasible interior solution exists.

To this, we first calculate the minimum of an expression of the form

$$
A=(k \alpha)^{\alpha}\left(\frac{k}{k-1}(1-\alpha)\right)^{1-\alpha} \text {, with } 0<\alpha<1, k>1 \text { : }
$$

$$
\begin{array}{rlrl}
\frac{\partial A}{\partial \alpha} & =0 \\
\Rightarrow & (k \alpha)^{\alpha}\left(\frac{k(1-\alpha)}{k-1}\right)^{1-\alpha} \ln \left(\frac{(k-1) \alpha}{(1-\alpha)}\right) & =0 \\
\Leftrightarrow & \frac{(k-1) \alpha}{(1-\alpha)} & =1 \\
\Leftrightarrow & \alpha & =\frac{1}{k} .
\end{array}
$$


The second-order condition is satisfied as

$$
\frac{\partial^{2} A}{\partial \alpha \partial \alpha}=(k \alpha)^{\alpha}\left(\frac{k(1-\alpha)}{k-1}\right)^{1-\alpha}\left(\left(\ln \left(\frac{(k-1) \alpha}{(1-\alpha)}\right)\right)^{2}+\frac{1}{1-\alpha}\right)>0
$$

and $\mathrm{A}$ obtains its minimum at $\alpha^{*}=\frac{1}{k}$ with value $\left(k \alpha^{*}\right)^{\alpha^{*}}\left(\frac{k}{k-1}\left(1-\alpha^{*}\right)\right)^{1-\alpha^{*}}=1$.

We can apply this insight to the following inequalities.

- $U\left(H_{a}^{*}, H_{b}=1\right)>U\left(H_{a}=0, H_{b}=1\right)$

$$
\begin{gathered}
\Rightarrow\left((2-\bar{D}) \alpha w_{a}\right)^{\alpha}((2-\bar{D})(1-\alpha))^{1-\alpha}>w_{a}^{\alpha}(1-\bar{D})^{1-\alpha} \\
\quad \Leftrightarrow((2-\bar{D}) \alpha)^{\alpha}\left(\left(\frac{2-\bar{D}}{1-\bar{D}}\right)(1-\alpha)\right)^{1-\alpha}>1
\end{gathered}
$$

which holds for all $\alpha \neq \frac{1}{2-\bar{D}}$.

- $U\left(H_{a}=0, H_{b}^{*}\right)>U\left(H_{a}=0, H_{b}=1\right)$

$$
\begin{gathered}
\Rightarrow\left(\left(w_{a}+w_{b}-w_{b} \bar{D}\right) \alpha\right)^{\alpha}\left(\left(\frac{w_{a}}{w_{b}}+1-\bar{D}\right)(1-\alpha)\right)^{1-\alpha}>w_{a}^{\alpha}(1-\bar{D})^{1-\alpha} \\
\Leftrightarrow\left(\frac{w_{a}+w_{b}-w_{b} \bar{D}}{w_{a}} \alpha\right)^{\alpha}\left(\frac{\frac{w_{a}}{w_{b}}+1-\bar{D}}{1-\bar{D}}(1-\alpha)\right)^{1-\alpha}>1
\end{gathered}
$$

which holds for all $\alpha \neq \frac{w_{a}}{w_{a}+w_{b}-w_{b} \bar{D}}$.

(ii) If $w_{a} \geq w_{b} \geq p_{D}$,

$$
\begin{array}{lll}
H_{a}^{*} \geq 0, H_{b}^{*}=1 & \text { if } & \alpha \leq \frac{w_{a}-p_{D} \bar{D}}{2 w_{a}-p_{D} \bar{D}} \\
H_{a}^{*}=0, H_{b}^{*} \leq 1 & \text { if } \quad \frac{w_{a}-p_{D} \bar{D}}{w_{a}+w_{b}-p_{D} \bar{D}} \leq \alpha .
\end{array}
$$

If $w_{a}=w_{b}$, then $\frac{w_{a}-p_{D} \bar{D}}{2 w_{a}-p_{D} \bar{D}}=\frac{w_{a}-p_{D} \bar{D}}{w_{a}+w_{b}-p_{D} \bar{D}}$. If $w_{a}>w_{b}, \frac{w_{a}-p_{D} \bar{D}}{2 w_{a}-p_{D} \bar{D}}<\frac{w_{a}-p_{D} \bar{D}}{w_{a}+w_{b}-p_{D} \bar{D}}$ and there are parameter values for $\alpha$ without an interior solution.

We show that full specialization, $H_{a}=0, H_{b}=1$, is only optimal if $\frac{w_{a}-p_{D} \bar{D}}{2 w_{a}-p_{D} \bar{D}} \leq \alpha \leq \frac{w_{a}-p_{D} \bar{D}}{w_{a}+w_{b}-p_{D} \bar{D}}$. We show also for (ii) that full specialization of the partners never yields highest utility if a feasible interior solution exists. 
- $U\left(H_{a}^{*}, H_{b}=1\right)>U\left(H_{a}=0, H_{b}=1\right)$

$$
\begin{aligned}
& \Rightarrow\left(\left(2 w_{a}-p_{D} \bar{D}\right) \alpha\right)^{\alpha}\left(\left(2-\frac{p_{D}}{w_{a}} \bar{D}\right)(1-\alpha)\right)^{1-\alpha}>\left(w_{a}-p_{D} \bar{D}\right)^{\alpha} \\
& \Leftrightarrow\left(\frac{2 w_{a}-p_{D} \bar{D}}{w_{a}-p_{D} \bar{D}} \alpha\right)^{\alpha}\left(\left(2-\frac{p_{D}}{w_{a}} \bar{D}\right)(1-\alpha)\right)^{1-\alpha}>1
\end{aligned}
$$

which holds for all $\alpha \neq \frac{w_{a}-p_{D} \bar{D}}{2 w_{a}-p_{D} \bar{D}}$.

- $U\left(H_{a}=0, H_{b}^{*}\right)>U\left(H_{a}=0, H_{b}=1\right)$

$$
\begin{gathered}
\Rightarrow\left(\left(w_{a}+w_{b}-p_{D} \bar{D}\right) \alpha\right)^{\alpha}\left(\frac{1}{w_{b}}\left(w_{a}+w_{b}-p_{D} \bar{D}\right)(1-\alpha)\right)^{1-\alpha}>\left(w_{a}-p_{D} \bar{D}\right)^{\alpha} \\
\Leftrightarrow\left(\frac{w_{a}+w_{b}-p_{D} \bar{D}}{w_{a}-p_{D} \bar{D}} \alpha\right)^{\alpha}\left(\frac{1}{w_{b}}\left(w_{a}+w_{b}-p_{D} \bar{D}\right)(1-\alpha)\right)^{1-\alpha}>1
\end{gathered}
$$

which holds for all $\alpha \neq \frac{w_{a}-p_{D} \bar{D}}{w_{a}+w_{b}-p_{D} \bar{D}}$.

(iii) If $w_{a}<w_{b}$ and $\lambda=0$ or sufficiently small, we obtain the solutions by reversing indices $a$ and $b$ in (i) and (ii).

(iv) If $w_{b}>w_{a}, \lambda>>0$, and $w_{b}<p_{D}$, we have the same solutions as under (i), despite now $\frac{1}{2-\bar{D}}>\frac{w_{a}}{w_{a}+w_{b}-w_{b} \bar{D}}$. In this case there are no parameter values for which full specialization yields highest utility. For the parameter range where $\frac{w_{a}}{w_{a}+w_{b}-w_{b} \bar{D}}<\alpha<\frac{1}{2-\bar{D}}$ we check which interior solution yields highest utility. Using the first- and second-order conditions of the utility maximization problem described above one can show that there exists $\hat{\alpha}^{(i v)}=\frac{\ln \left(\frac{w_{a}+w_{b}-w_{b} \bar{D}}{(2-D) b_{b}}\right)}{\ln \left(\frac{w_{w}}{w_{b}}\right)}$ for which

$U\left(H_{a}=H_{a}^{*}, H_{b}=1\right)>U\left(H_{a}=0, H_{b}=H_{b}^{*}\right)$ if $\alpha<\hat{\alpha}^{(i v)}$,

$U\left(H_{a}=H_{a}^{*}, H_{b}=1\right)<U\left(H_{a}=0, H_{b}=H_{b}^{*}\right)$ if $\alpha>\hat{\alpha}^{(i v)}$,

$U\left(H_{a}=H_{a}^{*}, H_{b}=1\right)=U\left(H_{a}=0, H_{b}=H_{b}^{*}\right)$ if $\alpha=\hat{\alpha}^{(i v)}$.

(v) If $w_{b}>w_{a}, \lambda>>0$, and $w_{b} \geq p_{D}$, we obtain the same solution as under (ii), despite now $\frac{w_{a}-p_{D} \bar{D}}{2 w_{a}-p_{D} \bar{D}}>\frac{w_{a}-p_{D} \bar{D}}{w_{a}+w_{b}-p_{D} \bar{D}}$. In this case there are also no parameter values for which full specialization yields highest utility. For the parameter range where $\frac{w_{a}-p_{D} \bar{D}}{w_{a}+w_{b}-p_{D} \bar{D}}<\alpha<\frac{w_{a}-p_{D} \bar{D}}{2 w_{a}-p_{D} \bar{D}}$ we check which interior solution yields highest utility. As in (iv) one can show that there exists $\hat{\alpha}^{(v)}=\frac{\ln \left(\frac{w_{a}^{2}+w_{a} w_{b}-w_{a} p_{D} \bar{D}}{2 w_{a} w_{b}-w_{b} p_{D} \bar{D}}\right)}{\ln \left(\frac{w_{a}}{w_{b}}\right)}$ for which

$U\left(H_{a}=H_{a}^{*}, H_{b}=1\right)>U\left(H_{a}=0, H_{b}=H_{b}^{*}\right)$ if $\alpha<\hat{\alpha}^{(v)}$,

$U\left(H_{a}=H_{a}^{*}, H_{b}=1\right)<U\left(H_{a}=0, H_{b}=H_{b}^{*}\right)$ if $\alpha>\hat{\alpha}^{(v)}$,

$U\left(H_{a}=H_{a}^{*}, H_{b}=1\right)=U\left(H_{a}=0, H_{b}=H_{b}^{*}\right)$ if $\alpha=\hat{\alpha}^{(v)}$. 


\section{Appendix B}

Additional Results

Female

Male

Both out of labor force, out of labor force, At least one partner in labor force male in labor force female in labor force retiree or student

\begin{tabular}{|c|c|c|c|c|}
\hline \multicolumn{5}{|l|}{ Female younger than 35} \\
\hline Non-migrants & $88.6 \%$ & $4.8 \%$ & $1.0 \%$ & $5.6 \%$ \\
\hline Migrants & $82.3 \%$ & $7.0 \%$ & $2.4 \%$ & $8.3 \%$ \\
\hline Nordic countries & $81.1 \%$ & $7.6 \%$ & $2.5 \%$ & $8.7 \%$ \\
\hline Non-Nordic countries & $82.6 \%$ & $6.5 \%$ & $2.2 \%$ & $8.7 \%$ \\
\hline United States & $81.2 \%$ & $6.9 \%$ & $1.5 \%$ & $10.4 \%$ \\
\hline Other Western countries & $83.2 \%$ & $6.8 \%$ & $2.6 \%$ & $7.4 \%$ \\
\hline Non-Western countries & $82.6 \%$ & $5.9 \%$ & $2.5 \%$ & $8.9 \%$ \\
\hline \multicolumn{5}{|l|}{ Female 35 or older } \\
\hline Non-migrants & $87.3 \%$ & $6.1 \%$ & $0.9 \%$ & $5.7 \%$ \\
\hline Migrants & $75.5 \%$ & $13.2 \%$ & $3.9 \%$ & $7.4 \%$ \\
\hline Nordic countries & $74.6 \%$ & $10.8 \%$ & $6.2 \%$ & $8.5 \%$ \\
\hline Non-Nordic countries & $75.8 \%$ & $13.8 \%$ & $3.3 \%$ & $7.1 \%$ \\
\hline United States & $70.4 \%$ & $17.6 \%$ & $4.9 \%$ & $7.0 \%$ \\
\hline Other Western countries & $79.9 \%$ & $11.4 \%$ & $2.6 \%$ & $6.2 \%$ \\
\hline Non-Western countries & $77.5 \%$ & $13.7 \%$ & $4.4 \%$ & $4.4 \%$ \\
\hline
\end{tabular}

Source: Register data.

Notes: Out of labor force excludes retirees and students.

Table B1. Labor force participation in Denmark.

\begin{tabular}{lcc} 
Stated own and partner's preferences & $\begin{array}{c}\text { Preferences towards } \\
\text { emigration }\end{array}$ & $\begin{array}{c}\text { Preferences towards } \\
\text { partners' labor force participation }\end{array}$ \\
\hline Partners' answers match & $81.7 \%$ & $66.7 \%$ \\
Partners' answers don't match & $18.3 \%$ & $21.7 \%$ \\
No answer & $0.0 \%$ & $11.7 \%$ \\
& & 60 \\
Observations & 60 &
\end{tabular}

Table B2. Mutual assessment of partner's preferences among couples with both partners as survey respondents. 


\begin{tabular}{lcccc} 
& $\begin{array}{c}\text { Both in the } \\
\text { labor force }\end{array}$ & $\begin{array}{c}\text { Male in the } \\
\text { labor force, } \\
\text { female home }\end{array}$ & $\begin{array}{c}\text { Female in the } \\
\text { labor force, } \\
\text { male home }\end{array}$ & $\begin{array}{c}\text { At least one partner } \\
\text { retiree or student }\end{array}$ \\
\hline In Denmark & $80.9 \%$ & $2.9 \%$ & $0.0 \%$ & $16.2 \%$ \\
United Kingdom & $84.9 \%$ & $3.0 \%$ & $0.0 \%$ & $12.1 \%$ \\
Other Western Europe & $89.7 \%$ & $0.0 \%$ & $0.0 \%$ & $10.3 \%$ \\
AUS, CAN, NZ & & & & \\
Abroad, in 2008 & $67.6 \%$ & $27.9 \%$ & $0.0 \%$ & $4.4 \%$ \\
United Kingdom & $66.3 \%$ & $27.7 \%$ & $1.2 \%$ & $4.8 \%$ \\
Other Western Europe & $75.9 \%$ & $20.7 \%$ & $0.0 \%$ & $3.5 \%$ \\
AUS, CAN, NZ & & & & \\
\hline
\end{tabular}

Source: Survey data.

Table B3. Percentage shares for actual labor force participation in other Western countries (without Nordic countries and the US).

\begin{tabular}{lccccc} 
& $\begin{array}{c}\text { Moth in the in the } \\
\text { labor force }\end{array}$ & $\begin{array}{c}\text { Female in the } \\
\text { labor force, } \\
\text { female home }\end{array}$ & $\begin{array}{c}\text { labor force, } \\
\text { male home }\end{array}$ & $\begin{array}{c}\text { Both } \\
\text { at home }\end{array}$ & No answer \\
\hline United Kingdom & $57.4 \%$ & $35.3 \%$ & $0.0 \%$ & $1.5 \%$ & $5.9 \%$ \\
Other Western Europe & $62.7 \%$ & $27.1 \%$ & $0.6 \%$ & $2.4 \%$ & $7.2 \%$ \\
AUS, CAN, NZ & $75.9 \%$ & $17.1 \%$ & $3.5 \%$ & $3.5 \%$ & $0.0 \%$ \\
\hline
\end{tabular}

Source: Survey data.

Table B4. Percentage shares for preferred labor force participation in other Western countries (without Nordic countries and the US).

\begin{tabular}{|c|c|c|c|c|c|}
\hline A: Household economy in DK & $\begin{array}{l}\text { Nordic } \\
\text { countr. }\end{array}$ & US & $\begin{array}{l}\text { Other } \\
\text { Western } \\
\text { countr. }\end{array}$ & $\begin{array}{l}\text { Non- } \\
\text { West. } \\
\text { countr. }\end{array}$ & Total \\
\hline Separate economies & $15.6 \%$ & $10.7 \%$ & $12.9 \%$ & $9.1 \%$ & $12.6 \%$ \\
\hline Joint economies, male brings in more & $54.1 \%$ & $75.0 \%$ & $58.9 \%$ & $78.8 \%$ & $63.0 \%$ \\
\hline Joint economies, female brings in more & $11.0 \%$ & $1.2 \%$ & $9.1 \%$ & $4.6 \%$ & $7.7 \%$ \\
\hline Joint economies, equal contributions & $11.9 \%$ & $10.7 \%$ & $14.4 \%$ & $7.6 \%$ & $12.5 \%$ \\
\hline Male brings in all money, female stays home & $6.4 \%$ & $1.2 \%$ & $3.0 \%$ & $0.0 \%$ & $3.1 \%$ \\
\hline Female brings in all money, male stays home & $0.0 \%$ & $1.2 \%$ & $0.4 \%$ & $0.0 \%$ & $0.4 \%$ \\
\hline No answer & $0.9 \%$ & $0.0 \%$ & $1.1 \%$ & $0.0 \%$ & $0.8 \%$ \\
\hline \multicolumn{6}{|l|}{ B: Household economy in 2008} \\
\hline Separate economies & $7.3 \%$ & $0.0 \%$ & $1.9 \%$ & $0.0 \%$ & $2.5 \%$ \\
\hline Joint economies, male brings in more & $47.7 \%$ & $47.6 \%$ & $55.1 \%$ & $54.6 \%$ & $52.3 \%$ \\
\hline Joint economies, female brings in more & $22.9 \%$ & $2.4 \%$ & $9.5 \%$ & $3.0 \%$ & $10.3 \%$ \\
\hline Joint economies, equal contributions & $14.7 \%$ & $6.0 \%$ & $8.8 \%$ & $3.0 \%$ & $8.8 \%$ \\
\hline Male brings in all money, female stays home & $5.5 \%$ & $44.1 \%$ & $22.4 \%$ & $37.9 \%$ & $24.3 \%$ \\
\hline Female brings in all money, male stays home & $1.8 \%$ & $0.0 \%$ & $1.1 \%$ & $1.5 \%$ & $1.2 \%$ \\
\hline No answer & $0.0 \%$ & $0.0 \%$ & $1.1 \%$ & $0.0 \%$ & $0.6 \%$ \\
\hline Observations & 109 & 84 & 263 & 66 & 522 \\
\hline
\end{tabular}

Source: Survey data.

Table B5. Percentage shares of household economies before migration and in 2008. 


$12.6 \%$

\section{Household economy in 2008}

\begin{tabular}{lcc}
\hline Separate economies & $1.5 \%$ & $3.6 \%$ \\
Joint economies, the male brings in more money & $56.1 \%$ & $48.2 \%$ \\
Joint economies, the female brings in more money & $10.0 \%$ & $10.8 \%$ \\
Joint economies, both partners bring in the same amount & $9.2 \%$ & $8.4 \%$ \\
Man brings in all money, female stays home & $21.0 \%$ & $27.9 \%$ \\
Woman brings in all money, male stays home & $1.1 \%$ & $1.2 \%$ \\
No answer & $1.1 \%$ & $0.0 \%$ \\
Observations & 271 & 251 \\
\hline
\end{tabular}

Source: Survey data.

Table B6. Percentage shares of household economies before migration and 2008 by year of emigration.

\begin{tabular}{lcccc} 
& $1987 / 1988$ & $1992 / 1993$ & $1997 / 1998$ & $2001 / 2002$ \\
\hline Nordic countries & $23.3 \%$ & $14.5 \%$ & $14.5 \%$ & $26.3 \%$ \\
United Kingdom & $2.3 \%$ & $11.6 \%$ & $12.6 \%$ & $15.5 \%$ \\
Rest of Western Europe & $37.2 \%$ & $44.9 \%$ & $34.6 \%$ & $25.5 \%$ \\
US & $18.7 \%$ & $16.0 \%$ & $20.1 \%$ & $13.2 \%$ \\
Other Western countries & $9.3 \%$ & $4.3 \%$ & $4.4 \%$ & $6.0 \%$ \\
Non-Western countries & $9.3 \%$ & $8.7 \%$ & $13.9 \%$ & $13.5 \%$ \\
Observations & 43 & 69 & 159 & 251 \\
\hline
\end{tabular}

Source: Survey data.

Table B7. Percentage shares of countries of residence by emigration years.

\begin{tabular}{lccc} 
A: All couples. & & Other & AUS, \\
& UK & Western Europe & CAN, NZ \\
\hline Male tied mover & $100.0 \%$ & $92.0 \%$ & $100.0 \%$ \\
& $(5)$ & $(25)$ & $(6)$ \\
No tied mover & $82.4 \%$ & $74.2 \%$ & $71.4 \%$ \\
& $(17)$ & $(31)$ & $(14)$ \\
Female tied mover & $65.2 \%$ & $64.5 \%$ & $77.8 \%$
\end{tabular}

(46) (110) (9)

B: Couples without pre-school age children.

\begin{tabular}{lccc}
\hline Male tied mover & $100.0 \%$ & $100.0 \%$ & $100.0 \%$ \\
& $(4)$ & $(16)$ & $(5)$ \\
No tied mover & $100.0 \%$ & $80.7 \%$ & $90.0 \%$ \\
& $(10)$ & $(26)$ & $(10)$ \\
Female tied mover & $69.0 \%$ & $64.2 \%$ & $83.3 \%$ \\
& $(29)$ & $(81)$ & $(6)$ \\
\hline
\end{tabular}

Source: Survey data.

Notes: Numbers of observation in parentheses.

Table B8. Female labor force participation and tied mover status among emigrant couples in other Western countries (without other Nordic countries and the US) in 2008. 


\begin{tabular}{|c|c|c|c|c|}
\hline Power couple & $\begin{array}{c}0.008 \\
(0.059)\end{array}$ & $\begin{array}{l}-0.013 \\
(0.060)\end{array}$ & $\begin{array}{c}0.017 \\
(0.057)\end{array}$ & $\begin{array}{c}0.028 \\
(0.058)\end{array}$ \\
\hline Female power couple & $\begin{array}{c}0.040 \\
(0.082)\end{array}$ & $\begin{array}{c}0.009 \\
(0.082)\end{array}$ & $\begin{array}{c}0.005 \\
(0.079)\end{array}$ & $\begin{array}{c}0.019 \\
(0.079)\end{array}$ \\
\hline Male power couple & $\begin{array}{c}-0.199^{* * *} \\
(0.070)\end{array}$ & $\begin{array}{c}-0.180^{* *} \\
(0.071)\end{array}$ & $\begin{array}{c}-0.155^{* *} \\
(0.068)\end{array}$ & $\begin{array}{c}-0.147^{* *} \\
(0.068)\end{array}$ \\
\hline Youngest child 0-6 & $\begin{array}{c}-0.233^{* * * *} \\
(0.068)\end{array}$ & $\begin{array}{c}-0.195^{* * *} \\
(0.067)\end{array}$ & $\begin{array}{c}-0.190^{* * *} \\
(0.066)\end{array}$ & $\begin{array}{c}-0.258^{* * *} \\
(0.075)\end{array}$ \\
\hline Youngest child $7+$ & $\begin{array}{c}-0.134^{* *} \\
(0.060)\end{array}$ & $\begin{array}{c}-0.122^{* *} \\
(0.059)\end{array}$ & $\begin{array}{c}-0.131^{* *} \\
(0.057)\end{array}$ & $\begin{array}{c}-0.171^{* * *} \\
(0.064)\end{array}$ \\
\hline Gini & & $\begin{array}{c}-2.188^{* * *} \\
(0.402)\end{array}$ & & \\
\hline Nordic countries & & & $\begin{array}{c}0.207^{* * *} \\
(0.053)\end{array}$ & $\begin{array}{c}0.061 \\
(0.103)\end{array}$ \\
\hline United States & & & $\begin{array}{c}-0.195^{* * *} \\
(0.056)\end{array}$ & $\begin{array}{c}-0.191^{* * *} \\
(0.056)\end{array}$ \\
\hline Non-Western countries & & & $\begin{array}{c}-0.130^{* *} \\
(0.064)\end{array}$ & $\begin{array}{c}-0.126^{* *} \\
(0.064)\end{array}$ \\
\hline Youngest child $0-6 *$ Nordic & & & & $\begin{array}{c}0.245^{*} \\
(0.130)\end{array}$ \\
\hline Youngest child $7+{ }^{*}$ Nordic & & & & $\begin{array}{c}0.145 \\
(0.129)\end{array}$ \\
\hline Female tied mover & $\begin{array}{c}-0.128^{* * *} \\
(0.045)\end{array}$ & $\begin{array}{c}-0.090^{* *} \\
(0.044)\end{array}$ & $\begin{array}{c}-0.069 \\
(0.044)\end{array}$ & $\begin{array}{l}-0.069 \\
(0.044)\end{array}$ \\
\hline Constant & $\begin{array}{c}0.811^{* * *} \\
(0.117)\end{array}$ & $\begin{array}{c}1.458^{* * *} \\
(0.165)\end{array}$ & $\begin{array}{c}0.706^{* * *} \\
(0.115)\end{array}$ & $\begin{array}{c}0.764^{* * *} \\
(0.121)\end{array}$ \\
\hline R-squared & 0.196 & 0.250 & 0.267 & 0.273 \\
\hline Observations & 474 & 437 & 474 & 474 \\
\hline
\end{tabular}

Sources: Survey and register data.

Notes: OLS estimation. Standard errors in parentheses.

Female age dummies included.

*** Significant at the 1 percent level.

** Significant at the 5 percent level.

* Significant at the 10 percent level.

Table B9. Female labor force participation 2008 and tied mover status. 
Preference for

Actual

female labor force

female labor force

participation

participation

\begin{tabular}{|c|c|c|}
\hline Power couple & $\begin{array}{c}0.016 \\
(0.070)\end{array}$ & $\begin{array}{l}-0.034 \\
(0.062)\end{array}$ \\
\hline Female power couple & $\begin{array}{l}-0.100 \\
(0.095)\end{array}$ & $\begin{array}{l}-0.023 \\
(0.084)\end{array}$ \\
\hline Male power couple & $\begin{array}{l}-0.160^{*} \\
(0.086)\end{array}$ & $\begin{array}{c}-0.184^{* *} \\
(0.075)\end{array}$ \\
\hline Youngest child 0-6 & $\begin{array}{l}-0.336 \\
(0.237)\end{array}$ & $\begin{array}{c}-0.941^{* * * *} \\
(0.207)\end{array}$ \\
\hline Youngest child $7+$ & $\begin{array}{c}-0.187^{* * *} \\
(0.070)\end{array}$ & $\begin{array}{c}-0.160^{* * *} \\
(0.061)\end{array}$ \\
\hline Gini & $\begin{array}{c}-2.141^{* * *} \\
(0.491)\end{array}$ & $\begin{array}{c}-1.811^{* * *} \\
(0.445)\end{array}$ \\
\hline "Starting well" index & $\begin{array}{c}0.170 \\
(0.291)\end{array}$ & $\begin{array}{c}0.955^{* * *} \\
(0.254)\end{array}$ \\
\hline Constant & $\begin{array}{c}1.700^{* * *} \\
(0.196)\end{array}$ & $\begin{array}{c}1.306^{* * *} \\
(0.179)\end{array}$ \\
\hline $\begin{array}{l}\text { R-squared } \\
\text { Observations }\end{array}$ & $\begin{array}{c}0.217 \\
369\end{array}$ & $\begin{array}{c}0.283 \\
397\end{array}$ \\
\hline \multicolumn{3}{|c|}{$\begin{array}{l}\text { Sources: Survey data, register data, and The Economist Intelligence Unit } \\
\text { Notes: OLS estimation. Standard errors in parentheses. } \\
\text { Female age dummies included. } \\
\text { *** Significant at the } 1 \text { percent level. } \\
\text { ** Significant at the } 5 \text { percent level. } \\
* \text { Significant at the } 10 \text { percent level. }\end{array}$} \\
\hline
\end{tabular}

Table B10. Linear probability regressions: Actual and preferred female labor force participation and "Starting Well" Index. 


\begin{tabular}{|c|c|c|c|c|}
\hline Power couple & $\begin{array}{l}-0.039 \\
(0.060)\end{array}$ & $\begin{array}{l}-0.067 \\
(0.060)\end{array}$ & $\begin{array}{l}-0.022 \\
(0.058)\end{array}$ & $\begin{array}{l}-0.010 \\
(0.058)\end{array}$ \\
\hline Female power couple & $\begin{array}{c}0.005 \\
(0.082)\end{array}$ & $\begin{array}{l}-0.033 \\
(0.082)\end{array}$ & $\begin{array}{l}-0.026 \\
(0.079)\end{array}$ & $\begin{array}{c}-0.012 \\
(0.079)\end{array}$ \\
\hline Male power couple & $\begin{array}{c}-0.255^{* * *} \\
(0.070)\end{array}$ & $\begin{array}{c}-0.234^{* * * *} \\
(0.071)\end{array}$ & $\begin{array}{c}-0.192^{* * *} \\
(0.067)\end{array}$ & $\begin{array}{c}-0.184^{* * *} \\
(0.067)\end{array}$ \\
\hline Youngest child $0-6$ & $\begin{array}{c}-0.211^{* * *} \\
(0.069)\end{array}$ & $\begin{array}{c}-0.168^{* *} \\
(0.067)\end{array}$ & $\begin{array}{c}-0.167^{* *} \\
(0.066)\end{array}$ & $\begin{array}{c}-0.234^{* * *} \\
(0.075)\end{array}$ \\
\hline Youngest child $7+$ & $\begin{array}{c}-0.136^{* *} \\
(0.060)\end{array}$ & $\begin{array}{c}-0.118^{* *} \\
(0.058)\end{array}$ & $\begin{array}{c}-0.124^{* *} \\
(0.057)\end{array}$ & $\begin{array}{c}-0.163^{* *} \\
(0.064)\end{array}$ \\
\hline Gini & & $\begin{array}{c}-2.289^{* * *} \\
(0.395)\end{array}$ & & \\
\hline Nordic countries & & & $\begin{array}{c}0.217^{* * *} \\
(0.053)\end{array}$ & $\begin{array}{c}0.073 \\
(0.103)\end{array}$ \\
\hline United States & & & $\begin{array}{c}-0.204^{* * *} \\
(0.055)\end{array}$ & $\begin{array}{c}-0.199^{* * *} \\
(0.055)\end{array}$ \\
\hline Non-Western countries & & & $\begin{array}{c}-0.144^{* *} \\
(0.063)\end{array}$ & $\begin{array}{c}-0.140^{* *} \\
(0.063)\end{array}$ \\
\hline Youngest child $0-6 *$ Nordic & & & & $\begin{array}{c}0.241^{*} \\
(0.129)\end{array}$ \\
\hline Youngest child $7+{ }^{*}$ Nordic & & & & $\begin{array}{c}0.142 \\
(0.128)\end{array}$ \\
\hline Female labor force participation in DK & $\begin{array}{c}0.309 * * \\
(0.121)\end{array}$ & $\begin{array}{c}0.381^{* * *} \\
(0.120)\end{array}$ & $\begin{array}{c}0.312^{* * *} \\
(0.116)\end{array}$ & $\begin{array}{c}0.309 * * * \\
(0.115)\end{array}$ \\
\hline Constant & $\begin{array}{c}0.445^{* * *} \\
(0.165)\end{array}$ & $\begin{array}{c}1.077^{* * *} \\
(0.201)\end{array}$ & $\begin{array}{c}0.363^{* *} \\
(0.159)\end{array}$ & $\begin{array}{c}0.424^{* * *} \\
(0.163)\end{array}$ \\
\hline R-squared & 0.193 & 0.261 & 0.275 & 0.281 \\
\hline Observations & 474 & 437 & 474 & 474 \\
\hline
\end{tabular}

Source: Survey and register data.

Notes: OLS estimation. Standard errors in parentheses.

Female age dummies included.

*** Significant at the 1 percent level.

** Significant at the 5 percent level.

* Significant at the 10 percent level.

Table B11. Linear probability regressions: Female labor force participation abroad in 2008. 


$$
\begin{gathered}
\text { Emigration } \\
87 / 88,92 / 93,97 / 98
\end{gathered}
$$

Preference for female labor force

Actual female labor force participation

\section{Emigration}

$01 / 02$

\begin{tabular}{|c|c|c|c|c|}
\hline Power couple & $\begin{array}{c}0.213 \\
(0.135)\end{array}$ & $\begin{array}{c}0.144 \\
(0.096)\end{array}$ & $\begin{array}{c}0.119 \\
(0.121)\end{array}$ & $\begin{array}{c}0.041 \\
(0.086)\end{array}$ \\
\hline Female power couple & $\begin{array}{c}0.059 \\
(0.188)\end{array}$ & $\begin{array}{c}0.048 \\
(0.128)\end{array}$ & $\begin{array}{c}0.002 \\
(0.167)\end{array}$ & $\begin{array}{c}0.095 \\
(0.114)\end{array}$ \\
\hline Male power couple & $\begin{array}{l}-0.056 \\
(0.148)\end{array}$ & $\begin{array}{c}0.009 \\
(0.119)\end{array}$ & $\begin{array}{l}-0.005 \\
(0.131)\end{array}$ & $\begin{array}{l}-0.126 \\
(0.104)\end{array}$ \\
\hline Youngest child 0-6 & $\begin{array}{c}-0.407^{* *} \\
(0.177)\end{array}$ & $\begin{array}{l}-0.168^{*} \\
(0.091)\end{array}$ & $\begin{array}{l}-0.260^{*} \\
(0.155)\end{array}$ & $\begin{array}{l}-0.160^{*} \\
(0.082)\end{array}$ \\
\hline Youngest child $7+$ & $\begin{array}{c}-0.287^{* *} \\
(0.143)\end{array}$ & $\begin{array}{c}-0.201^{* *} \\
(0.099)\end{array}$ & $\begin{array}{l}-0.217^{*} \\
(0.121)\end{array}$ & $\begin{array}{l}-0.121 \\
(0.089)\end{array}$ \\
\hline Nordic countries & $\begin{array}{c}0.153 \\
(0.136)\end{array}$ & $\begin{array}{c}0.207^{* *} \\
(0.081)\end{array}$ & $\begin{array}{c}0.240^{* *} \\
(0.119)\end{array}$ & $\begin{array}{c}0.200^{* * *} \\
(0.073)\end{array}$ \\
\hline United States & $\begin{array}{c}-0.382^{* * *} \\
(0.112)\end{array}$ & $\begin{array}{c}-0.206^{* *} \\
(0.101)\end{array}$ & $\begin{array}{c}-0.355^{* * *} \\
(0.099)\end{array}$ & $\begin{array}{c}-0.221^{* *} \\
(0.091)\end{array}$ \\
\hline Non-Western countries & $\begin{array}{l}-0.035 \\
(0.125)\end{array}$ & $\begin{array}{c}0.078 \\
(0.109)\end{array}$ & $\begin{array}{l}-0.199^{*} \\
(0.111)\end{array}$ & $\begin{array}{l}-0.174^{*} \\
(0.097)\end{array}$ \\
\hline Constant & $\begin{array}{c}1.041^{* *} \\
(0.505)\end{array}$ & $\begin{array}{c}0.817^{* * *} \\
(0.144)\end{array}$ & $\begin{array}{c}0.900^{*} \\
(0.467)\end{array}$ & $\begin{array}{c}0.606^{* * *} \\
(0.131)\end{array}$ \\
\hline $\begin{array}{l}\text { Observations } \\
\text { R-squared }\end{array}$ & $\begin{array}{c}132 \\
0.353\end{array}$ & $\begin{array}{c}220 \\
0.273\end{array}$ & $\begin{array}{c}143 \\
0.421\end{array}$ & $\begin{array}{c}234 \\
0.350\end{array}$ \\
\hline
\end{tabular}

\begin{tabular}{cc} 
Preference for & Actual \\
female labor force & female labor force \\
participation & participation \\
\hline
\end{tabular}

Source: Survey and register data.

Notes: OLS estimation. Standard errors in parentheses.

Female age dummies included.

*** Significant at the 1 percent level.

** Significant at the 5 percent level.

* Significant at the 10 percent level.

Table B12. Preferred and actual female labor force participation separately for earlier and later emigration cohorts. 


\section{Appendix C}

\section{Regression Results with Sample Weighting}

Tables $\mathrm{C} 1$ and $\mathrm{C} 2$ show regression specifications as in Tables 14 and 15 using inverse probability weights which account for the probability that an individual is included in our sample. We construct these weights following the propensity cell method described in Cochran (1986) and Lewis (2012). In the administrative population data, we can observe the target population of emigrants who satisfy the restrictions to be included in the survey according to the sampling design. To be included in the survey, individuals must have emigrated in 1987, 1988, 1992, 1993, 1997, 1998, 2001 or 2002, and must not have returned by the end of 2007. Emigrants had to be aged 18 or more when they emigrated, and at most 59 in 2007. As the probability for an individual to be included in our sample depends, for example, on the availability of contact information and on response behavior, this can potentially induce a bias in our regression results if this sample selection is non-random. To account for a potential bias in our results we first estimate a logit model predicting the probability for an individual to be in the sample based on a set of observable characteristics, including gender, emigration year, destination country, age and education. These variables are included as dummy variables derived from the following categories: We distinguish between male and female individuals, 4 emigration year-pairs, 4 age categories intervals (22-29, 30-39, 40-49, 50-59), as well as destination country groups as presented in Table 2, excluding emigrants to the Faroe Islands and Greenland. As weighting of survey responses is based on the initial destination country of the migrants according to the administrative data, we exclude some observations for which information on the initial emigration country differs from our information in the survey. According to the probabilities predicted by the model we calculate the share of respondents in five strata of equal size in the migrant population, as suggested by Cochran (1968). The inverse of these shares are then used as probability weights in the regressions in Tables C1 and C2. The results do not show any qualitative difference to the unweighted regressions. The similarity of the results with and without weighting alleviates the concern that a potential sample selection bias affects our results. 


\begin{tabular}{|c|c|c|c|c|}
\hline Power couple & $\begin{array}{c}-0.032 \\
(0.069)\end{array}$ & $\begin{array}{c}-0.069 \\
(0.063)\end{array}$ & $\begin{array}{l}-0.033 \\
(0.066)\end{array}$ & $\begin{array}{c}-0.014 \\
(0.067)\end{array}$ \\
\hline Female power couple & $\begin{array}{c}0.061 \\
(0.080)\end{array}$ & $\begin{array}{l}-0.016 \\
(0.075)\end{array}$ & $\begin{array}{l}0.0018 \\
(0.074)\end{array}$ & $\begin{array}{c}0.019 \\
(0.073)\end{array}$ \\
\hline Male power couple & $\begin{array}{c}-0.227^{* * *} \\
(0.086)\end{array}$ & $\begin{array}{c}-0.185^{* *} \\
(0.086)\end{array}$ & $\begin{array}{c}-0.157^{*} \\
(0.088)\end{array}$ & $\begin{array}{c}-0.148^{*} \\
(0.088)\end{array}$ \\
\hline Youngest child 0-6 & $\begin{array}{c}-0.137^{*} \\
(0.072)\end{array}$ & $\begin{array}{r}-0.130^{*} \\
(0.068)\end{array}$ & $\begin{array}{c}-0.125^{*} \\
(0.066)\end{array}$ & $\begin{array}{c}-0.203^{* *} \\
(0.091)\end{array}$ \\
\hline Youngest child $7+$ & $\begin{array}{c}-0.099 \\
(0.069)\end{array}$ & $\begin{array}{c}-0.108 \\
(0.067)\end{array}$ & $\begin{array}{c}-0.113^{*} \\
(0.064)\end{array}$ & $\begin{array}{l}-0.147^{*} \\
(0.079)\end{array}$ \\
\hline Gini & & $\begin{array}{c}-2.045^{* * *} \\
(0.490)\end{array}$ & & \\
\hline Nordic countries & & & $\begin{array}{c}0.149^{* * *} \\
(0.052)\end{array}$ & $\begin{array}{c}0.031 \\
(0.073)\end{array}$ \\
\hline United States & & & $\begin{array}{c}-0.232^{* * *} \\
(0.074)\end{array}$ & $\begin{array}{c}-0.228^{* * *} \\
(0.073)\end{array}$ \\
\hline Non-Western countries & & & $\begin{array}{c}-0.207^{* *} \\
(0.096)\end{array}$ & $\begin{array}{c}-0.206^{* *} \\
(0.097)\end{array}$ \\
\hline Youngest child $0-6 *$ Nordic & & & & $\begin{array}{c}0.229^{* *} \\
(0.104)\end{array}$ \\
\hline Youngest child $7+{ }^{*}$ Nordic & & & & $\begin{array}{c}0.103 \\
(0.113)\end{array}$ \\
\hline Constant & $\begin{array}{c}0.731^{* * *} \\
(0.132)\end{array}$ & $\begin{array}{c}1.378^{* * *} \\
(0.181)\end{array}$ & $\begin{array}{c}0.699 * * * \\
(0.122)\end{array}$ & $\begin{array}{c}0.754^{* * *} \\
(0.128)\end{array}$ \\
\hline R-squared & 0.177 & 0.235 & 0.261 & 0.268 \\
\hline Observations & 451 & 419 & 451 & 451 \\
\hline
\end{tabular}

Sources: Survey and register data.

Notes: Weighted linear probability regressions. Standard errors in parentheses.

Female age dummies included.

$* * *$ Significant at the 1 percent level.

** Significant at the 5 percent level.

* Significant at the 10 percent level.

Table C1. Weighted linear probability regressions: Female labor force participation abroad in 2008. 


\begin{tabular}{|c|c|c|c|c|}
\hline Power couple & $\begin{array}{c}0.069 \\
(0.072)\end{array}$ & $\begin{array}{c}0.025 \\
(0.068)\end{array}$ & $\begin{array}{c}0.078 \\
(0.072)\end{array}$ & $\begin{array}{c}0.101 \\
(0.073)\end{array}$ \\
\hline Female power couple & $\begin{array}{c}0.002 \\
(0.096)\end{array}$ & $\begin{array}{l}-0.082 \\
(0.094)\end{array}$ & $\begin{array}{l}-0.039 \\
(0.090)\end{array}$ & $\begin{array}{l}-0.021 \\
(0.088)\end{array}$ \\
\hline Male power couple & $\begin{array}{l}-0.111 \\
(0.089)\end{array}$ & $\begin{array}{l}-0.120 \\
(0.093)\end{array}$ & $\begin{array}{l}-0.056 \\
(0.093)\end{array}$ & $\begin{array}{l}-0.044 \\
(0.092)\end{array}$ \\
\hline Youngest child 0-6 & $\begin{array}{c}-0.227^{* * *} \\
(0.073)\end{array}$ & $\begin{array}{c}-0.210^{* * *} \\
(0.072)\end{array}$ & $\begin{array}{c}-0.220^{* * *} \\
(0.070)\end{array}$ & $\begin{array}{c}-0.318^{* * *} \\
(0.092)\end{array}$ \\
\hline Youngest child 7+ & $\begin{array}{c}-0.255^{* * *} \\
(0.067)\end{array}$ & $\begin{array}{c}-0.232^{* * *} \\
(0.070)\end{array}$ & $\begin{array}{c}-0.256^{* * *} \\
(0.067)\end{array}$ & $\begin{array}{c}-0.297^{* * *} \\
(0.075)\end{array}$ \\
\hline Gini & & $\begin{array}{c}-1.921^{* * *} \\
(0.515)\end{array}$ & & \\
\hline Nordic countries & & & $\begin{array}{c}0.176^{* * *} \\
(0.060)\end{array}$ & $\begin{array}{c}0.041 \\
(0.089)\end{array}$ \\
\hline United States & & & $\begin{array}{c}-0.195^{* *} \\
(0.078)\end{array}$ & $\begin{array}{c}-0.192^{* *} \\
(0.076)\end{array}$ \\
\hline Non-Western countries & & & $\begin{array}{l}-0.014 \\
(0.089)\end{array}$ & $\begin{array}{l}-0.014 \\
(0.088)\end{array}$ \\
\hline Youngest child $0-6 *$ Nordic & & & & $\begin{array}{l}0.280^{* *} \\
(0.110)\end{array}$ \\
\hline Youngest child $7+{ }^{*}$ Nordic & & & & $\begin{array}{c}0.103 \\
(0.136)\end{array}$ \\
\hline Constant & $\begin{array}{c}0.975^{* * *} \\
(0.115)\end{array}$ & $\begin{array}{c}1.588^{* * *} \\
(0.179)\end{array}$ & $\begin{array}{c}0.920^{* * *} \\
(0.121)\end{array}$ & $\begin{array}{c}0.985^{* * *} \\
(0.129)\end{array}$ \\
\hline R-squared & 0.165 & 0.222 & 0.222 & 0.232 \\
\hline Observations & 420 & 391 & 420 & 420 \\
\hline
\end{tabular}

Sources: Survey and register data.

Notes: Weighted linear probability regressions. Standard errors in parentheses.

Female age dummies included.

$* * *$ Significant at the 1 percent level.

** Significant at the 5 percent level.

* Significant at the 10 percent level.

Table C2. Weighted linear probability regressions: Preference for female labor force participation. 